\title{
GIF NATURAL RADIOCARBON MEASUREMENTS VII
}

\author{
G. DELIBRIAS, M. T. GUILLIER, and J. LABEYRIE
}

Centre des Faibles Radioactivités, Centre National de la

Recherche Scientifique, (91) Gif-sur-Yvette, France

$\mathrm{C}^{14}$ dates reported below were obtained mainly at the end of 1968 and during 1969 on archaeologic and geologic samples. Techniques of measurement used are unchanged. Since 1968, 4 complete routine sets have been running, each equipped with a $1 \mathrm{~L} \mathrm{CO}^{2}$ proportional counter. One is made of stainless steel with a background of $2.70 \mathrm{cpm}$ at pressure $1 \mathrm{~atm}$ and the others are of OFHC copper with a background of either 1.10 or $1.30 \mathrm{cpm}$ for a corresponding pressure of, respectively, 1 or 2 atm. For age calculation, $95 \%$ activity of NBS oxalic acid is used as the modern standard and the value of $5570 \pm 30$ years is used for the halflife of $\mathrm{C}^{14}$. Dates are expressed in years B.P. (before A.D. 1950).

\section{ACKNOWLEDGMENTS}

Thanks are due Inès Mirre and Madeleine Kolbach for routine sample preparation and to Michel Jaudon for his assistance with electronic equipment.

$$
\text { I. ARCHAEOLOGIC SAMPLES }
$$

A. France

\section{W France}

\section{La Hoguette, Fontenay-le-Marmion series, Calvados}

Charcoal from Neolithic cairn at La Hoguette, Fontenay-le-Marmion $\left(49^{\circ} 05^{\prime} 50^{\prime \prime} \mathrm{N}\right.$ Lat, $0^{\circ} 22^{\prime} 10^{\prime \prime} \mathrm{W}$ Long), Calvados. Coll. and subm. 1968, 1969 by R. Caillaud and E. Lagnel, Caen.

Gif-1347. La Hoguette, La/41

$3750 \pm 120$

Exterior limit of Crematorium.

Gif-1346. La Hoguette, J/42 1800 B.C.

Interior of Crematorium.

Gif-1514. La Hoguette, La/43

$4300 \pm 120$

2350 B.c.

Carbonized log in low structure of Crematorium.

$4720 \pm 130$ 2770 B.c.

Gif-1513. La Hoguette, La/42

$4800 \pm 130$

Carbonized log in low structure of Crematorium.

2850 B.C.

Gif-1348. La Hoguette, I/32

$4820 \pm 130$

Hearth, outside monument.

2870 B.C.

Gif-1345. La Hoguette, P/45

$5000 \pm 130$

Hearth under sepulchral Chamber V. 
General Comment (E.L.): coherent results except for crematorium, used once only, according to the archaeologists.

\section{Gif-1248. Vrasville, Manche}

A.D. 1090

$860 \pm 100$

Charcoal, from remains of stone-construction, under feudal moat of the 12 th century, at Vrasville $\left(49^{\circ} 42^{\prime} \mathrm{N}\right.$ Lat, $1^{\circ} 22^{\prime} \mathrm{W}$ Long), Manche. Coll. and subm. 1968 by M. de Boüard, Centre de Recherches Archéol. Médiévales, Caen. Comment: dates 1st occupation of site.

\section{Gif-1315. Penvern, Saint-Servais, Finistère}

$1020 \pm 100$

Charcoal from pit, $1 \mathrm{~m}$ deep, near Penvern, Saint-Servais $\left(48^{\circ} 32^{\prime}\right.$ N Lat, $4^{\circ} 12^{\prime}$ W Long), Finistère. Coll. and subm. 1968 by P. R. Giot, Fac. Sci., Rennes. Comment: indicates existence of Middle Age habitation area.

\section{Gif-1463. Fouesnant, Finistère}

Charcoal from room of a passage grave on Brunec I., Fouesnant $\left(47^{\circ} 25^{\prime} \mathrm{N}\right.$ Lat, $3^{\circ} 59^{\prime} \mathrm{W}$ Long), Finistère. Coll. and subm. 1969 by C. T. Le Roux, Fac. Sci., Rennes. Comment: late reutilization of site.

\section{Gif-1187. Pors-Rolland, Perros-Guirec, Côtes du Nord \\ $1300 \pm 100$ \\ A.D. 650}

Charcoal from brickwork site, Pors-Rolland, Perros-Guirec $\left(48^{\circ} 50^{\prime}\right.$ N Lat, $3^{\circ}$ 29' W Long), Côtes du Nord. Coll. by M. Le Goffic and subm. 1968 by P. L. Gouletquer, Fac. Sci., Rennes. Comment: surface contaminated; insufficiently sheltered.

Gif-1466. Kervignac, Plussulien, Côtes du Nord

$$
\begin{array}{r}
1500 \\
\text { A.D. } 450
\end{array}
$$

Charcoal from filling of a souterrain at Kervignac, Plussulien $\left(48^{\circ}\right.$ $22^{\prime} \mathrm{N}$ Lat, $3^{\circ} 05^{\prime} \mathrm{W}$ Long), Côtes du Nord. Coll. and subm. by C. T. Le Roux. Comment: indicates late re-use.

\section{Gif-1304. Keradennec, Saint-Frégant, Côtes du Nord \\ $1760 \pm 100$ \\ A.D. 190}

Charcoal and ashes from praefurnium of a Gallo-Roman villa, Keradennec, Saint-Frégant (48 $34^{\prime} \mathrm{N}$ Lat, $4^{\circ} 22^{\prime} \mathrm{W}$ Long), Côtes du Nord. Coll. and subm. 1968 by R. Sanquer, Fac. Lettres, Brest. Comment: fits well with archaeologic clues: terra sigillata made by a well-known potter, Paternus, from Lezoux (A.D. 150 to 193); a sesterce of Emperor Commode coined in A.D. 184; late 2nd century style of painting in fresco on walls of room heated by praefurnium (Sanquer and Galliou, 1970).

\section{Gif-1186. Bel-Air, Treby, Côtes du Nord}

$1830 \pm 100$

Charcoal from Iron age souterrain, Bel-Air, Treby $\left(48^{\circ} 20^{\prime} \mathrm{N}\right.$ Lat, $2^{\circ} 35^{\prime}$ W Long), Côtes du Nord (Gouletquer, 1969). Coll. and subm. 
1968 by P. L. Gouletquer. Comment: typical early La Tène ceramics assoc.; proves slight admixture of more recent charcoal.

\section{Gif-1190. Castellou-Péron, Saint-Jean-Trolimon, $\quad 2000 \pm 100$ Finistère \\ 50 B.C.}

Charcoal from Iron age souterrain, Castellou-Péron, Saint-JeanTrolimon (47 $03^{\prime} \mathrm{N}$ Lat, $4^{\circ} 07^{\prime} \mathrm{W}$ Long), Finistère. Coll. and subm. 1968 by P. L. Gouletquer. Comment: slightly too young, but contamination is probable; site was not sealed.

\section{Gif-1303. Kersulvez, Pluzunet, Côtes du Nord}

$$
\begin{aligned}
& 2210 \pm 110 \\
& 260 \text { B.C. }
\end{aligned}
$$

Charcoal from Iron age souterrain, at Pluzunet $\left(48^{\circ} 38^{\prime} \mathrm{N}\right.$ Lat, $3^{\circ}$ 22' W Long), Côtes du Nord. Coll. and subm. 1968 by P. R. Giot. Comment: agrees well with assoc. ceramics (Castel and Giot, 1968).

Gif-1188. Le Gouffre, Plougrescant, Côtes du Nord

$2450 \pm 105$

500 B.c.

Charcoal in hearth from habitation site on top of rock, Le Gouffre, Plougrescant (48 52' N Lat, $3^{\circ} 15^{\prime} \mathrm{W}$ Long), Côtes du Nord. Coll. and subm. 1968 by P. L. Gouletquer. Comment: agrees with assoc. ceramics debris.

\section{Gif-1189. Le Frèche, Plémy, Côtes du Nord}

$2500 \pm 105$

550 в.c.

Charcoal from Iron age souterrain, Le Frèche, Plémy $\left(48^{\circ} 20^{\prime} \mathrm{N}\right.$ Lat, $2^{\circ} 40^{\prime} \mathrm{W}$ Long), Côtes du Nord. Coll. and subm. 1968 by P. L. Gouletquer (1969). Comment: slightly older than assoc. ceramics of early La Tène age.

Gif-1464. Ergué-Gabéric, Saint-André, Finistère

$$
2650 \pm 110
$$$$
700 \text { B.C. }
$$

Charcoal from grave in Middle Bronze age barrow, Ergué-Gabéric, Saint-André (48 $01^{\prime} \mathrm{N}$ Lat, $3^{\circ} 59^{\prime} \mathrm{W}$ Long), Finistère. Coll. and subm. 1969 by C. T. Le Roux. Comment: contaminated by a younger occupation of site.

\section{Gif-1149. Kernonen, Plouvorn, Finistère, D}

Charcoal from grave in Early Bronze age barrow, Kernonen, Plouvorn (48 $35^{\prime} \mathrm{N}$ Lat, $4^{\circ} 03^{\prime} \mathrm{W}$ Long), Finistère. Coll. and subm. 1968 by J. Briard, Fac. Sci., Rennes. Comment: completes dates already pub. (Gif-805-807: R., 1971, v. 13, p. 214) for tumulus of 1st Breton series.

\section{Goarem Goasven series, Berrien, Finistère}

Charcoal in soil of Bronze age barrow without funeral room, an uncommon type of barrow, at Goarem Goasven, Berrien ( $48^{\circ} 24^{\prime} \mathrm{N}$ Lat, $3^{\circ} 47^{\prime}$ W Long), Finistère. Coll. and subm. by J. Briard.

Gif-1313. Goarem Goasven I

$3800 \pm 130$

W part. 


\section{Gif-1314. Goarem Goasven II}

$\mathrm{N}$ part.

General Comment: Gif-1313 supposedly belongs to level anterior to barrow erection.

\section{Gif-1462. Portsall-Kerdéniel, Ploudalmezeau, $\quad 23,000 \pm 1100$ Finistère \\ 21,050 в.c.}

Carbonized brushwood in fossil sand hill over an ancient shore, ca. +2 related m.s.l. (mean sea level), and covered with $6 \mathrm{~m}$ silty grit, Portsall-Kerdéniel, Ploudalmezeau (48 $34^{\circ} \mathrm{N}$ Lat, $4^{\circ} 41^{\prime} \mathrm{W}$ Long), Finistère. Coll. and subm. 1969 by P. R. Giot. Comment: this date applies to dunes, but without relation to ancient shore.

Gif-1312. Trozoul, Trébeurden, Côtes du Nord

$\geqslant 35,000$

Charcoal from hearth, $+6 \mathrm{~m}$ related to m.s.l., on shingle bar fossil shore, covered with solifluction material, $3 \mathrm{~m}$ thick, at Trozoul, Trebeurden $\left(48^{\circ} 46^{\prime} \mathrm{N}\right.$ Lat, $3^{\circ} 35^{\prime} \mathrm{W}$ Long), Côtes du Nord. Coll. and subm. 1968 by P. R. Giot. Comment: probably 1st Würm interstadial or rather Riss-Würm interglacial (Giot, 1969).

\section{Gif-1467. La Chênaie, Abbaretz, Loire Atlantique A.d. 650}

$1300 \pm 100$

Piece of wood, at $2.10 \mathrm{~m}$ under alluvium of la Chênaie R., Abbaretz (47 $33^{\prime}$ N Lat, $1^{\circ} 32^{\prime}$ W Long), Loire Atlantique. Coll. and subm. 1969 by J. Guigues, B.R.G.M., Rennes. Comment: traces of works of tin placer in upper levels; 2 gold coins struck at Vannes and Nantes ca. A.D. 550-560 were found at some distance from site (Giot, 1970).

\section{Gif-1112. Butte-aux-Pierres, Saint-Joachim, $\quad 3200 \pm 120$ Loire Atlantique \\ 1250 B.c.}

Charcoal, $40 \mathrm{~cm}$ deep, from Neolithic level with Chasseen pottery types, La Butte-aux-Pierres, Saint-Joachim $\left(47^{\circ} 23^{\prime} \mathrm{N}\right.$ Lat, $2^{\circ} 10^{\prime} \mathrm{W}$ Long), Loire Atlantique. Coll. and subm. 1967 by G. Bellancourt, Nantes. Comment: disagrees with archaeologic clues; site is Neolithic.

\section{ORS series, Oléron Is., Charente Maritime}

Charcoal and burnt bones from "Peu Richardien" Neolithic site, on foreshore, ORS ( $45^{\circ} 21^{\prime} \mathrm{N}$ Lat, $3^{\circ} 31^{\prime} \mathrm{W}$ Long), Oléron Is., Charente Maritime. Coll. and subm. 1968 by C. Gabet, Rochefort-sur-Mer, Charente Maritime.

\section{Gif-1329. ORS III, E 5-2}

$4070 \pm 120$

2120 B.C.

Gif-1330. ORS III, wall

$4080 \pm 120$

2130 B.c.

General Comment: younger than continental sites of La Garenne and Les Matignons with very similar ceramics dated 4790, 4560 and 4570 
B.P. (Gif-313 and Gif-417: R., 1970, v. 12, p. 435 and Gsy-32: R., 1966, v. 8, p. 131).

Gif-1128. Grotte des Terriers, Lussac-les-Châteaux, Vienne

$10,450 \pm 250$

8500 B.c.

Charcoal and carbonized bones from archaeologic level of Grotte des Terriers, Lussac-les-Châteaux $\left(46^{\circ} 20^{\prime} \mathrm{N}\right.$ Lat, $1^{\circ} 30^{\prime} \mathrm{W}$ Long). Coll. and subm. 1968 by G. Lwoff, Paris. Comment: flint implements assoc., different animals engraved on walls of cave indicate Magdalenian age.

\section{Gif-1007. La Bachellerie, Compreignac, Haute Vienne, Co F I}

$1040 \pm 100$ A.D. 910

Charcoal from filling of souterrain at La Bachellerie, Compreignac $\left(46^{\circ} 00^{\prime} \mathrm{N}\right.$ Lat, $1^{\circ} 17^{\prime} \mathrm{E}$ Long), Haute Vienne. Coll. and subm. 1967 by P. Saumande, Limoges, Haute Vienne. Comment: agrees with age of numerous sherds from souterrain.

Gif-1008. La Courrière, Saint Sulpice Laurière, Haute Vienne, Ba F I

$750 \pm 100$

A.D. 1200

Charcoal from filling of souterrain at La Courrière, Saint Sulpice Laurière $\left(46^{\circ} 03^{\prime} \mathrm{N}\right.$ Lat, $1^{\circ} 28^{\prime} \mathrm{E}$ Long), Haute Vienne. Coll. and subm. 1967 by P. Saumande. Comment: agrees with numerous sherds assoc.

\section{2. $S$ France}

\section{Gif-1275. Grotte des Châtaigniers, Vingrau, $\quad 3430 \pm 120$ Pyrénées Orientales \\ 1480 B.C.}

Burnt grain from Early Bronze age level, in sepulchral grotte des Châtaigniers, Casenove-Vingrau (42 $51^{\prime} \mathrm{N}$ Lat, $2^{\circ} 47^{\prime} \mathrm{E}$ Long) (Guilaine and Abelanet, 1965). Coll. and subm. 1968 by J. Guilaine, C.N.R.S., Carcassonne. Comment: a lst date of this level obtained with charcoal: 3120 в.P. (Gif-760: R., 1971, v. 13, p. 219) was considered too young and charcoal was supposedly late intrusion into level related to industry. This 2nd date fits much better with Early Bronze industry.

\section{Gif-1088. Cuxac, Aude}

$1920 \pm 110$

Charcoal from Gallo-Roman villa, Cuxac $\left(43^{\circ} 16^{\prime} \mathrm{N}\right.$ Lat, $2^{\circ} 58^{\prime}$ E Long), Aude. Coll. and subm. 1968 by P. Bouisset, Ouveillan. Comment: agrees well.

\section{Gif-1359. Grotte du Hasard, Tharaux, Gard}

$2950 \pm 130$

1000 B.c.

Charcoal from Middle Bronze age Level 2, Rm. I.G., Grotte du Hasard, Tharaux (44 $14^{\prime} \mathrm{N}$ Lat, $4^{\circ} 19^{\prime} \mathrm{E}$ Long), Gard. Coll. and subm. 1969 by J. L. Roudil, Montpellier, Hérault. Comment: slightly too young for assoc. industry. 
Gif-1161. "Les Courondes", Ouveillan, Aude

Charcoal from Chalcolithic site (Bouisset and Guilaine, 1966), "Les Courondes", Ouveillan (43 $18^{\prime} \mathrm{N}$ Lat, $2^{\circ} 58^{\prime} \mathrm{E}$ Long), Aude. Coll. and subm. by P. Bouisset. Comment: in expected age range.

\section{Gif-1093. Grotte de Resplandy, Hérault}

$4050 \pm 140$ 2100 в.c.

Charcoal from ritual hearth from Grotte de Resplandy $\left(43^{\circ} 29^{\prime} \mathrm{N}\right.$ Lat, $2^{\circ} 45^{\prime}$ E Long), Hérault. Coll. and subm. 1968 by G. Rodriguez, Underground Lab., C.N.R.S., Moulis, Ariège. Comment: agrees with middle Chalcolithic with typical copper awl (Rodriguez, 1968).

\section{Gif-1360. Grotte des Pins, Blandas, Gard}

$4350 \pm 130$ 2400 B.c.

Charcoal in ashes, from Late Neolithic site, Grotte des Pins, Blandas

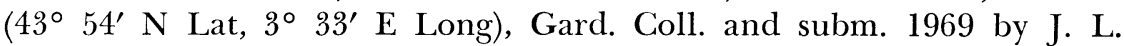
Roudil. Comment: fits well with Late Neolithic industry of "Ferrière culture."

\section{Gif-1274. Grotte de Gaougnas, Cabrespine, Aude}

$4610 \pm 140$

Charcoal from Late Neolithic level of Grotte de Gaougnas, Cabrespine $\left(43^{\circ} 21^{\prime} \mathrm{N}\right.$ Lat, $2^{\circ} 27^{\prime} \mathrm{E}$ Long), Aude. Coll. and subm. 1968 by J. Guilaine. Comment: agrees well with industry and ceramics.

\section{Gif-1273. Grotte de Gazel, Sallèles, Aude}

$5950 \pm 150$

4000 B.c.

Charcoal from level without ceramics just under Early Neolithic levels of Grotte de Gazel, Sallèles (43 $19^{\prime} \mathrm{N}$ Lat, $2^{\circ} 25^{\prime}$ E Long), Aude. Coll. and subm. 1968 by J. Guilaine. Comment: agrees with stratigraphy.

\section{Grotte de Camprafaud series, Ferrière-Poussarou, Hérault}

Grotte de Camprafaud is one of numerous cavities in Devonian dolomite, all occupied by prehistoric men, in N W Hérault. Grotte de Camprafaud, Ferrière-Poussarou $\left(43^{\circ} 26^{\prime} \mathrm{N}\right.$ Lat, $2^{\circ} 54^{\prime} \mathrm{E}$ Long) showed a continuous stratigraphy, from Late Bronze to Early Neolithic age. Charcoal coll. and subm. 1967-1969 by G. Rodriguez.

Gif-1091. Camprafaud, Level 3

$3080 \pm 110$

Comment: disagrees with Early Bronze age industry assoc.

\section{Gif-1092. Camprafaud, Level 6}

$3920 \pm 135$

1970 в.c.

Gif-1156. Camprafaud, Level 9

$4300 \pm 140$

Comment: presence of 2 copper slags. 
Gif-1157. Camprafaud, Level 10

2400 B.c.

Comment: typical Neolithic of region, different from Mediterranean Neolithic.

Gif-1484. Camprafaud, Level 12

$4900 \pm 130$

Last level of middle Neolithic period (Chassean).

2950 B.C.

Gif-1485. Camprafaud, Level 13

$5100 \pm 130$

Middle Neolithic period.

Gif-1486. Camprafaud, Level 14

3150 B.c.

First level of Early Languedocian Neolithic.

$5450 \pm 130$

3500 B.C.

Gif-1487. Camprafaud, Level 15

$5300 \pm 130$

Early Languedocian Neolithic.

Gif-1488. Camprafaud, Level 16

3350 B.c.

Middle level of Early Languedocian Neolithic.

$5900 \pm 140$

3950 в.c.

Gif-1489. Camprafaud, Level 17

$5900 \pm 140$

Similar to Gif-1488.

3950 B.C.

Gif-1490. Camprafaud, Level 18

$5800 \pm 140$

Similar to Gif-1489.

3850 B.c.

Gif-1491. Camprafaud, Level 19

$6300 \pm 140$

4350 в.c.

Early Cardial Neolithic. Comment: corresponds to arrival of 1st Neolithic people in region.

General Comment: Levels 9 and 10 date an important and brutal transference of population shown by disappearance of Chassean industry. It seems to correspond to moist, torrential climatic phase.

Grotte des Sarrazins series, Seyssinet-Pariset, Isère

Grotte des Sarrazins ( $45^{\circ} 23^{\prime}$ N Lat, $5^{\circ} 40^{\prime}$ E Long), Seyssinet-Pariset, near Grenoble, Isère, is a large rock shelter, with $3 \mathrm{~m}$ habitation soils, uninterrupted from Gallo-Roman to Chalcolithic ages. Charcoal coll. and subm. 1968 by A. Bocquet, Grenoble.

Gif-1201. Grotte des Sarrazins, SAR 4

$2500 \pm 105$

Assoc. with Hallstatt C ceramics.

550 B.c.

Gif-1202. Grotte des Sarrazins, SAR 7

$2980 \pm 105$

Assoc. with Late Bronze age II ceramics.

1030 B.C. 
Gif-1203. Grotte des Sarrazins, SAR 19

$3320 \pm 110$

Assoc. with Late Bronze age I to Early Middle Bronze age ceramics.

Gif-1204. Grotte des Sarrazins, SAR 28

$3900 \pm 120$

Assoc. with Early Chalcolithic age ceramics.

General Comment: in spite of remote situation of site from protohistoric currents, it appears that all material fits well with archaeologic context of E France (Bocquet and Papet, 1966). Coherent with results obtained by Lyon Radiocarbon Lab. for same site (R., 1971, v. 13, p. $55-56)$.

\section{Baudinard series, Var}

Charcoal from Grotte de l'Eglise supérieure, with 7 Neolithic levels, all belonging to Chassean, Baudinard (43 $45^{\prime} \mathrm{N}$ Lat, $6^{\circ} 15^{\prime} \mathrm{E}$ Long), Var. Coll. and subm. 1968-1970 by J. Courtin, C.N.R.S., Marseille.

\section{Gif-1332. Grotte de l'Eglise supérieure, $\quad 4200 \pm 130$ Level 5}

Late Chassean with Chalcolithic rudiments.
Gif-1331. Grotte de l'Eglise supérieure, $\quad 4500 \pm 130$ Level 3 2550 в.c.

Late Chassean with Chalcolithic rudiments.

Gif-1621. Grotte C

$4800 \pm 140$

Middle Chassean.

2850 B.C.

Gif-1333. Grotte de l'Eglise supérieure, Early Chassean.

\section{Level 8A}

$5500 \pm 140$

3550 в.c.

Gif-1334. Grotte de l'Eglise supérieure, Level 8B $\quad \begin{array}{ll}\mathbf{3 8 6 0} \pm 140 \\ \mathbf{3 8 1 0}\end{array}$

Base level with Early Chassean.

General Comment: places evolution of Chassean in Provence (Courtin, 1968, 1970).

\section{Gif-1111. "Abri du Capitaine", Sainte-Croix-de- $\quad 6050 \pm 150$ Verdon, Basses-Alpes \\ 4100 в.c.}

Charcoal from Level 18 separated from upper and low levels by sterile layers in rock shelter, "Abri du Capitaine", Sainte-Croix-de-Verdon $\left(43^{\circ} 45^{\prime} \mathrm{N}\right.$ Lat, $6^{\circ} 10^{\prime} \mathrm{E}$ Long), Basses-Alpes. Coll. and subm. 1967 by J. Courtin. Comment: agrees with Cardial type Early Neolithic industry. A chalcolithic level was dated 4100 B.P. (Gif-704, R., 1970, v. 12, p. 427). 


\section{Gif-1224. Faycelles, Lot}

$$
740 \pm 90
$$

A.D. 1210

Human jaw from site of ancient lazar house, at bottom of cave in hillside, Faycelles (44 $34^{\prime} \mathrm{N}$ Lat, $1^{\circ} 59^{\prime} \mathrm{E}$ Long), Lot. Coll. and subm. 1968 by G. Delbos, Caussade, Lot. Comment: locates previously known but unlocated ancient lazar house.

\section{Gif-1328. Grotte de la Fée, Thémines, Lot}

Burnt grain, corn and barley, from hearth of furnace in Level

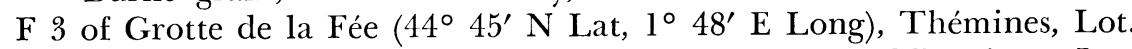
Coll. and subm. 1969 by M. Lorblanchet, C.N.R.S., Thémines, Lot. Comment: Early Iron age.

\section{Les Barbilloux series, Dordogne}

Charcoal from Neolithic ossuary in cave, Les Barbilloux, SaintAquilin $\left(45^{\circ} 11^{\prime} \mathrm{N}\right.$ Lat, $0^{\circ} 30^{\prime} \mathrm{E}$ Long), Dordogne. Coll. and subm. 1967 by G. Camps, Fac. Lettres, Aix-en-Provence.

Gif-1086. Les Barbilloux, B A R 1

Modern

Gif-1087. Les Barbilloux, B A R 5

Comment: corresponds to Early Bronze age, as expected.

\section{Grotte du Noyer series, Esclauzels, Lot}

Charcoal from Grotte du Noyer, Esclauzels $\left(44^{\circ} 27^{\prime} \mathrm{N}\right.$ Lat, $1^{\circ} 36^{\prime}$ W Long), Lot. Coll. 1966 and subm. 1969 by J. Clottes, Montgauzy, Ariège.

Gif-1160. Grotte du Noyer, II

Bottom of Level 2, of so-called civilization of "Champs d'Urnes".

Gif-1631. Grotte du Noyer, A D 8

$3150 \pm 110$

Hearth in Level 2; archaeologic clue of a new typical civilization of Middle Bronze age in region.

\section{Gif-1159. Grotte du Noyer, I}

Charcoal and grain in unbroken vase, Level 3, of Middle Bronze age.

Gif-1632. Grotte du Noyer, A E 7.8

Level 4 of Early Bronze age. Comment: slightly too old for a level containing copper: possibly contaminated from lower levels by gnawing. 
Gif-1634. Grotte du Noyer, A E 7

$3840 \pm 120$

Hearth 7. Comment: probable intrusion from upper level into Late Chassean level.

\section{Gif-1633. Grotte du Noyer, A E 8}

$5000 \pm 130$

Level 5, Chassean Neolithic age.

Gif-1635. Grotte du Noyer, A T C I 3050 B.c.

Level 5, well separated from Middle Bronze age by sterile level; assoc. with incinerated human bones.

General Comment: coherent with site stratigraphy according to archaeologic clues.

\section{Grotte des Eglises series, Ussat, Ariège}

Charcoal from Late Magdalenean site of Grotte des Eglises, Ussat $\left(42^{\circ} 49^{\prime} \mathrm{N}\right.$ Lat, $1^{\circ} 37^{\prime} \mathrm{E}$ Long), Ariège. Coll. and subm. 1967-1969 by P. Renault, C.N.R.S., Moulis, Ariège.

\section{Gig-1158. Grotte des Eglises, I}

Comment: disagreement with assoc. flints.

\section{B.C.}

\section{Gif-1434. Grotte des Eglises, 2}

$11,800 \pm 500$

Comment: inert carbon added for measurement. Correct date, agrees with archaeologic data.

\section{Gif-1354. Carbon, Varilhes, Ariège, F.C.I.}

Charcoal from habitation site in open air, in Ariège Valley, Carbon, Varilhes (43 03' N Lat, $1^{\circ} 38^{\prime}$ E Long), Ariège (Simonnet, 1970). Coll. and subm. 1969 by R. Simonnet, Foix. Comment: corresponds to Early Bronze age.

\section{Central France}

\section{Gif-1225. Le Razat, Laqueuille, Puy-de-Dôme}

Charcoal from hearth, from site of several hundred huts dug from altered basalt flow, alt.: $1100 \mathrm{~m}$, on Mt. Le Razat, Laqueuille $\left(45^{\circ} 38^{\prime}\right.$ 00" N Lat, 2० 44' 40" E Long), Puy-de-Dôme. Coll. and subm. 1968 by S. Paul, Fac. Sci., Orsay.

\section{Montbani series, Mont-Notre-Dame, Aisne}

Montbani site, Mont-Notre-Dame $\left(49^{\circ} 16^{\prime} 30^{\prime \prime} \mathrm{N}\right.$ Lat, $\mathrm{l}^{\circ} 14^{\prime} 40^{\prime \prime}$ E Long), Aisne, is workshop or encampment with well-defined stratigraphy. Coll. and subm. 1967-1968 by R. Parent, La Fère-en-Tardenois, Aisne. 


\section{Gif-355. Montbani, 2}

Hazel nut shells, $0.90 \mathrm{~m}$ deep, overlying Tardenoisian level.

\section{0 в.c.}

$6930 \pm 170$

Gif-1106. Montbani, 3

4980 в.c.

Charcoal from small hearths, 30 to $40 \mathrm{~cm}$ under Iron-age level. Comment: supposedly from Tardenoisian level; either contaminated by upper charcoal or belongs to same level as Gif-355.

\section{Gif-356. Montbani, 1}

$8060 \pm 350$

Charcoal from hearth, $1.20 \mathrm{~m}$ deep, lying on basal crushed stone. Comment: dates Tardenoisian.

\section{Coincy series, Aisne}

La Sablonnière de Coincy $\left(49^{\circ} 10^{\prime} \mathrm{N}\right.$ Lat, $1^{\circ} 57^{\prime} \mathrm{E}$ Long) is Tardenoisian workshop, rich in artifacts of predominantly triangular forms. Coll. and subm. by R. Parent.

\section{Gif-1107. Coincy I}

$4760 \pm 140$ 2810 B.c.

Charcoal under Neolithic and Iron-age levels, $45 \mathrm{~cm}$ thick. Comment: supposed Tardenoisian level. Either contaminated by upper charcoal or belongs to lower Neolithic level.

\section{Gif-1266. Coincy 2}

$8190 \pm 190$

Charcoal from hearth at bottom of Tardenoisian level, protected by clayey level, without charcoal in upper level.

General Comment: same date for deepest level at Montbani and Coincy, which are very close together and typologically similar. Pollen analysis disagrees, probably due to pollen infiltration in sandy material, in both places. Best results are obtained, in both cases, for hearths protected by clayey levels.

\section{Gif-1090. Clair Bois, Bressey, Côte d'Or}

$$
2000 \pm 100
$$
50 B.c.

Charcoal from incineration in barrow at Clair Bois farm, Bressey $\left(47^{\circ} 18^{\prime} \mathrm{N}\right.$ Lat, $5^{\circ} 11^{\prime} \mathrm{E}$ Long), Côte d'Or. Coll. and subm. 1967 by R. Ratel, Fac. Sci., Dijon. Comment: disagrees with Late Hallstatt sepulchres.

\section{Gif-1109. Chaume-Les-Baigneux, Côte d'Or}

Charcoal from incineration in barrow at Chaume-Les-Baigneux $\left(47^{\circ}\right.$ $38^{\prime}$ N Lat, 4 34' E Long), Côte d'Or. Coll. and subm. 1967 by R. Ratel. Comment: sepulchres from Late Bronze-Early Hallstatt period; agrees well. 


\section{Gif-1108. Chantrans, Doubs}

Human bones, 0.20 to $0.40 \mathrm{~m}$ deep, Chantrans $\left(47^{\circ} 18^{\prime} \mathrm{N}\right.$ Lat, $2^{\circ} 48^{\prime}$ E Long), Doubs. Coll. and subm. 1967 by A. Gauthier, Besançon. Comment: related to some Gallo-Roman vestiges around Chantrans.

Gif-1253. Niderbronn-des-Bains, Bas-Rhin

$$
1880 \pm 100
$$

Charcoal, $70 \mathrm{~cm}$ depth, at foot of rock decorated with concentric circles, Niderbronn-des-Bains, Wintersberg Cliff $\left(48^{\circ} 58^{\prime} 30^{\prime \prime} \mathrm{N}\right.$ Lat, $7^{\circ}$ $36^{\prime}$ 30" E Long), Bas-Rhin. Coll. and subm. 1968 by C. Lenoble, Strasbourg, Bas-Rhin. Comment: brings no interesting information on engravings.

\section{B. North Africa}

Gif-890. Djorf Torba, Saoura, D J, T 4, Algeria

Modern

Charcoal from lower level of Rooms-barrow 28, Djorf Torba, Saoura (31 $30^{\prime} \mathrm{N}$ Lat, $2^{\circ} 30^{\prime} \mathrm{W}$ Long). Coll. and subm. 1967 by G. Camps. Comment: expected age 1700 B.P.

Gif-1120. El Mermouta, Ouled Djellal, Algeria

$540 \pm 100$

Charred bone in $30 \mathrm{~cm}$ ashy level of Upper Capsian, El Mermouta (34 $35^{\prime} \mathrm{N}$ Lat, 5 $5^{\circ} 21^{\prime} \mathrm{E}$ Long), Ouled Djellal. Coll. and subm. 1967 by G. Camps. Comment: either a recent bone was introduced into this superficial layer or date obtained from total carbon bone is wrong.

\section{Guettara Wadi series, Bredea, Oran, Algeria}

Charcoal from burial cave of Guettara Wadi, Bredea $\left(35^{\circ} 36^{\prime} \mathrm{N}\right.$ Lat, $1^{\circ} 10^{\prime} \mathrm{W}$ Long), Oran. Site of Neolithic facies of Oran dist. with sepulchres of Mechta el Arbi type. Coll. and subm. 1967 by G. Camps.

\section{Gif-881. Guettara, O E G I}

A.D. 1400

$$
550 \pm 95
$$

25 to $45 \mathrm{~cm}$ depth. Comment: Neolithic ceramics assoc.; probably polluted by burrowing animals.

Gif-882. Guettara, O E G 2

$$
\begin{aligned}
& 10,190 \pm 230 \\
& 8240 \text { в.C. }
\end{aligned}
$$

90 to $100 \mathrm{~cm}$ depth. Comment: pre-Neolithic industry, without ceramics, corresponds to Late Iberomaurusian period.

\section{Gif-883. Station du Meandre, Brezina, Algeria 3900 B.c.}

Charcoal in archaeologic layer at foot of rupestral paintings, Sta. du Meandre (33 $06^{\prime} \mathrm{N}$ Lat, $1^{\circ} 15^{\prime} \mathrm{E}$ Long), Brezina. Coll. and subm. by G. Camps. Comment: confirms attribution of these paintings to Neolithic of Capsian tradition. 
Gif-884. Safiet Bou Rhenan, Medea, Algeria

Charcoal in typical Neolithic site with ceramics in ashy sand, Safiet Bou Rhenan (34 $23^{\prime} \mathrm{N}$ Lat, $3^{\circ} 27^{\prime} \mathrm{E}$ Long), Medea. Comment: oldest date known for Neolithic with ceramics. Confirms opinion that Neolithic appeared earlier in Saharian region than in $\mathbf{N}$ of Atlas.

\section{Medjez II series, El-Eulma, Algeria}

Medjez II, near El-Eulma town $\left(36^{\circ} 08^{\prime} \mathrm{N}\right.$ Lat, $5^{\circ} 40^{\prime} \mathrm{E}$ Long), Algeria, is a snail-shell heap, ("escargotière") of Upper Capsian, with $3.65 \mathrm{~m}$ archaeologic layer. Stratigraphy established through evolution of lithic industry: upper part is characterized by presence of geometric microliths and numerous slotted tools; in lower part, size and number of large tools increase with depth. Coll. and subm. 1967 by G. Camps.

Gif-885. Medjez, M J Z, II, 3

Hearth, depth $0.90 \mathrm{~m}$. Comment: diluted with inert carbon.

Gif-886. Medjez, M J Z II, 4

$7900 \pm 180$

Depth 0.73 to $1.00 \mathrm{~m}$.

Gif-887. Medjez, M J Z II, 5

$270 \pm 185$

Depth 1.00 to $1.30 \mathrm{~m}$.

Gif-888. Medjez, M J Z II, 6

Depth 1.30 to $1.80 \mathrm{~m}$.

Gif-889. Medjez, M J Z II, 7

5830 в.c.

Depth 2.30 to $3.20 \mathrm{~m}$. Comment: diluted with inert carbon.

General Comment: upper level dated 6620 B.P. by Gif-462 (R., 1970, v. 12, p. 436). Very coherent, but Gif-888 similar to MC-214: 7200 B.P. for 1.80 to $1.90 \mathrm{~m}$ (R., 1969, v. 11, p. 124). Shows evolution of Setif facies of Upper Capsian during 1000 yr. Gif-889 oldest date known for this civilization.

Aïn Naga series, Algeria

Charcoal from Aïn Naga ( $34^{\circ} 21^{\prime} \mathrm{N}$ Lat, $3^{\circ} 29^{\prime}$ E Long), Messad, Titteri Dept. Coll. and subm. 1968 by G. Camps.

Gif-1221. Aïn Naga, A N G 3 $7500 \pm 220$ 5550 B.c.

Lower part of Neolithic level. Comment: diluted with inert carbon.

Gif-1220. Aïn Naga, A N G 2

$9170 \pm 200$

Upper Capsian level.

General Comment: both dates are somewhat too old. 


\section{Gif-879. Koudiat Kifen Lahda, Constantine, Algeria}

$8540 \pm 200$

6590 B.C.

Charcoal from lower level of snail shell deposit, Koudiat Kifen Lahda, Aïn $\mathrm{M}^{\prime}$ Lila ( $36^{\circ} 02^{\prime} \mathrm{N}$ Lat, $6^{\circ} 30^{\prime}$ E Long), Constantine. Coll. and subm. 1967 by G. Camps. Comment: dates a microlithic industry prior to Upper Capsian. Similar to MC-207: 8320 B.P. (R., 1969, v. 11, p. 125).

\section{Gif-880. El Hadjar, Oasis, Algeria}

$7300 \pm 170$ 5350 в.c.

Charcoal, $1 \mathrm{~m}$ deep in sand, El Hadjar, Oasis $\left(31^{\circ} 27^{\prime} \mathrm{N}\right.$ Lat, $4^{\circ}$ $45^{\prime}$ E Long). Coll. and subm. by G. Camps. Comment: assoc. with epipaleolithic industry with lamella different from Iberomaurusian and Capsian industries.

\section{Gif-1222. Amekni, Oasis, A M K 4, Algeria}

$6800 \pm 220$

Charcoal from open-air site of Amekni, 60 to $90 \mathrm{~cm}$ depth, $40 \mathrm{~km}$ N.W. Tamanrasset, Oasis $\left(22^{\circ} 55^{\prime} \mathrm{N}\right.$ Lat, $5^{\circ} 15^{\prime} \mathrm{E}$ Long). Coll. and subm. by G. Camps. Comment: complex site which also includes Neolithic of Sudanese tradition, dated 8050 B.P. by UW-87 (unpub.) and MC212 (R., 1969, v. 11, p. 127).

\section{Gif-1195. Hassi-Mouillah, Ouargla, Oasis, Algeria $\quad \mathbf{5 7 0 0}$ в.c.}

Charcoal from level F I, including Neolithic of Capsian tradition with stamped ceramics (Marmier and Trecolle, 1968), Hassi-Mouillah $\left(32^{\circ} 08^{\prime} \mathrm{N}\right.$ Lat, $5^{\circ} 07^{\prime} \mathrm{E}$ Long), Oasis dist. Coll. and subm. 1968, by G. Trecolle, Ouargla. Comment: lower level dated 8600 B.P., MC-150 (R., 1969, v. 11, p. 126). All these dates are classified and commented upon in Camps et al. (1968).

\section{Gif-1316. Enneri Dirennao, N.E. Bardaï, Tibesti}

$$
1570 \pm 100
$$

Charcoal in rock shelter, Enneri Dirennao, N.E. Bardaï $\left(21^{\circ} 21^{\prime}\right.$ $\mathrm{N}$ Lat, $16^{\circ} 56^{\prime} \mathrm{E}$ Long), Tibesti. Coll. and subm. 1968 by K. Kaiser. Comment: Neolithic age was expected.

\section{Zouar series, Tibesti, Tchad}

Charcoal, under sand hill in rock shelter, $18 \mathrm{~km} \mathrm{~W}$ Zouar, Tibesti $\left(20^{\circ} 25^{\prime} \mathrm{N}\right.$ Lat, $16^{\circ} 23^{\prime} \mathrm{E}$ Long), Tchad. Coll. and subm. 1967 by K. Kaiser.

Gif-1126. Zouar 9

Modern

$30 \mathrm{~cm}$ depth.

Gif-1318. Zouar 12 f

$750 \pm 90$

120 to $125 \mathrm{~cm}$ depth.

\section{A.D. 1200}

General Comment: rock shelters may have been inhabited very recently; sand accumulation by wind is very rapid. 


\section{Zouar series, N Chad}

Samples from Zouar region, Tibesti $\left(20^{\circ} 29^{\prime} \mathrm{N}\right.$ Lat, $16^{\circ} 35^{\prime} \mathrm{E}$ Long), N Chad. Coll. and subm. 1968 by J. P. Roset, O.R.S.T.O.M., Fort-Lamy.

\section{Gif-1181. Zouar, 1}

$1330 \pm 100$

Charcoal from pre-Islamic sepulchre with incineration.

\section{Gif-1182. Zouar, 2}

Charcoal from ashy level, 20 to $30 \mathrm{~cm}$ deep, in Neolithic site. Comment: assoc. obsidian industry is typical for Zouar region.

\section{Gif-1183. Zouar, 3}

$3375 \pm 120$

1425 B.c.

Human bones, $1.40 \mathrm{~m}$ deep, in one of many sepulchres of Sahara. Comment: usually attributed to beginning of Christian era.

General Comment: diversity of ages for these vestiges from small area in Sahara. Fills in hiatus between Neolithic and protohistoric ages for that region.

\section{Chad series, République Centre-Afrique}

Charcoal from 3 Sao sites in Chad. Continuation of study begun in 1948 by J. P. and A. M. D. Lebeuf (R,. 1970, v. 12, p. 438). Coll. and subm. 1966 to 1969 by J. P. and A. M. D. Lebeuf, Lab. d'Ethnol. et d'Archeol. Tchadiennes et Camerounaises, Paris and Inst. Nat. Tchadien Sci. Hum., Fort-Lamy.

Gif-740. Mdaga IV, $3.20 \mathrm{~m}$ depth (12 12' 45" N Lat, 15 3' 30" E Long)

Gif-741. Mdaga IV, $4.20 \mathrm{~m}$ depth ( $12^{\circ} 12^{\prime} 45^{\prime \prime} \mathrm{N}$ Lat, $15^{\circ} 3^{\prime} 30^{\prime \prime}$ E Long)

Gif-742. Mdaga IV, $4.90 \mathrm{~m}$ depth

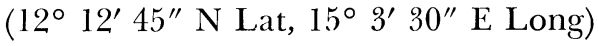

Gif-1171. Mdaga XII, A, $3.80 \mathrm{~m}$ depth (12 $12^{\prime} 45^{\prime \prime} \mathrm{N}$ Lat, $15^{\circ} 3^{\prime} 30^{\prime \prime} \mathrm{E}$ Long)

Gif-1172. Mdaga XII, B, $3.80 \mathrm{~m}$ depth $\left(12^{\circ} 12^{\prime} 45^{\prime \prime} \mathrm{N}\right.$ Lat, $15^{\circ} 3^{\prime} 30^{\prime \prime} \mathrm{E}$ Long)

Gif-1367. Mdaga VIII, $0.90 \mathrm{~m}$ depth $\left(12^{\circ} 12^{\prime} 45^{\prime \prime} \mathrm{N}\right.$ Lat, $15^{\circ} 3^{\prime} 30^{\prime \prime}$ E Long) Comment: coherent with results obtained by Dakar $\mathrm{C}^{14}$ Lab. for same site (Lebeuf, 1969).
$910 \pm 100$

A.D. 1040

A.D. 690

$2375 \pm 150$

425 B.c.

A.D. 1200

A.D. 1270

$$
680 \pm 95
$$

$170 \pm 90$

\section{A.D. 1780}

$750 \pm 95$$$
170 \pm 90
$$

(1)


Gif-1365. Gawi I, A 19, 1.20 to $1.50 \mathrm{~m}$ depth in sepulchre

(12 $10^{\prime} 30^{\prime \prime} \mathrm{N}$ Lat, $15^{\circ} 09^{\prime} 15^{\prime \prime}$ E Long)

A.D. 1800

Gif-1364. Gawi I, A 18, 2.00 m depth $\left(12^{\circ} 10^{\prime} 30^{\prime \prime} \mathrm{N}\right.$ Lat, $15^{\circ} 09^{\prime} 15^{\prime \prime}$ E Long)

Gif-1369. Amkoundjo II, $1.70 \mathrm{~m}$ depth (12 $21^{\prime} 15^{\prime \prime} \mathrm{N}$ Lat, $15^{\circ} 02^{\prime} 20^{\prime \prime}$ E Long)

Gif-1371. Amkoundjo II, $2.60 \mathrm{~m}$ depth (12 $21^{\prime} 15^{\prime \prime} \mathrm{N}$ Lat, $15^{\circ} 02^{\prime} 20^{\prime \prime}$ E Long)

Gif-1370. Amkoundjo I, $1.80 \mathrm{~m}$ depth (12 $21^{\prime} 15^{\prime \prime} \mathrm{N}$ Lat, $15^{\circ} 02^{\prime} 20^{\prime \prime}$ E Long)

$$
\begin{aligned}
& 860 \pm 90 \\
& \text { A.d. } 1090 \\
& 2100 \pm 100 \\
& 150 \text { B.c. }
\end{aligned}
$$

$2050 \pm 100$

100 в.c.

$$
2300 \pm 100
$$

350 B.c.

General Comment: oldest date for a tchadien site, i.e., 425 B.c. (Gif-742, Mdlaga) corresponds to oldest date, 450 B.c., for Sao site of Daimo, Nigeria. Despite some resemblance between industries there is no real basis for comparison of archaeologic discoveries in these regions (J.P.L.).

Gif-1282. Lemdena, Akjoujt, Mauritania

Modern

Charcoal in hearth from ancient brass-foundry, at Lemdena, $60 \mathrm{~km}$ S S W Akjoujt, Mauritania (19 $19^{\circ} 19^{\prime} \mathrm{N}$ Lat, $14^{\circ} 30^{\prime} \mathrm{W}$ Long). Coll. and subm. 1969 by N. Lambert, Athens, Greece. Comment: charcoal from recent hearth, no relation to archaeologic site.

\section{"Grotte aux Chauves-Souris" series, Akjoujt, Mauritania}

Grotte aux Chauves-Souris is not a cave but a series of excavations in $\mathrm{N}$ flank of Guelb Moghrein (19 $45^{\prime} \mathrm{N}$ Lat, $14^{\circ} 25^{\prime} \mathrm{W}$ Long), remains of important copper mine, with indications of ore treatment on the spot. Filling is made of alternated levels of rubble stones, broken copper ore, charcoal, slag, and ashes. Charcoal coll. and subm. 1968-1970 by $\mathrm{N}$. Lambert.

Gif-1284. Grotte aux Chauves-Souris, 1, A I-2 $0.60 \mathrm{~m}$ depth.

Gif-1285. Grotte aux Chauves-Souris, 1, A I-1 $1.90 \mathrm{~m}$ depth.

$2350 \pm 110$ 400 B.c.

Gif-1286. Grotte aux Chauves-Souris, 3 B S II-9 1.60 to $1.85 \mathrm{~m}$ depth

Gif-1287. Grotte aux Chauves-Souris, 3, A S I-9 
Gif-1822. Grotte aux Chauves-Souris, 1, 111

$7 \mathrm{~m}$ depth.

Gif-1823. Grotte aux Chauves-Souris, 1, 112

$8 \mathrm{~m}$ depth.

Gif-1824. Grotte aux Chauves-Souris, 1, 115

$8 \mathrm{~m}$ depth.

Gif-1825. Grotte aux Chauves-Souris, 1, 116

$10 \mathrm{~m}$ depth.

$$
2460 \pm 100
$$

510 B.C.

$2700 \pm 100$

750 B.C.

$2500 \pm 100$

550 в.C.

$2460 \pm 100$

510 B.c.

General Comment: dates agree well, except for Gif-1823. Important quantity of wood used for ore treatment suggests vegetation now nonexistent in this desert region.

\section{Niani series, Guinea}

Charcoal from ruins of Niani $\left(11^{\circ} 22^{\prime} \mathrm{N}\right.$ Lat, $8^{\circ} 23^{\prime} \mathrm{W}$ Long), Guinea. Coll. 1968 by W. Fillipowiak and subm. 1968, 1971 by R. Mauny, Fac. Lettres et Sci. Humaines, Paris.

\section{Gif-1291. Niani, 5 \\ Gif-1915. Niani, 8 \\ Gif-1916. Niani, 10 \\ Gif-1292. Niani, 13}

$1400 \pm 100$ A.D. 550 A.D. 1650

$300 \pm 90$

$$
1020 \pm 90
$$
A.D. 930

$1200 \pm 100$ A.D. 750

General Comment: doubt remains whether site was capital of Medieval Empire of Mali; dates are either older or younger than those for this hypothesis (Filipowiak, 1968).

\section{Gif-1361. Saqqarah, Egypt}

$3000 \pm 110$ 1050 B.c.

Wood from sarcophagus in royal tomb of III dynasty, Saqqarah (29 $51^{\prime} \mathrm{N}$ Lat, $31^{\circ} 14^{\prime} \mathrm{E}$ Long), Egypt. Coll. and subm. 1969 by J. P. Lauer, Paris. Comment: according to authors, IIIrd dynasty, at beginning of Ancient Empire, is estimated at either 28th century B.c. or 27 th century в.c.; ca. 1500 yr difference is unexplained but, interestingly, wood is badly conserved.

\section{Latin America}

\section{Temple of Sechin series, Casma, Peru}

Samples from mummy from Temple of Sechin $\left(9^{\circ} 30^{\prime} \mathrm{S}\right.$ Lat, $78^{\circ}$ 18' W Long), Casma, Peru. Subm. 1968 by J. V. Macchiavello, Patronato Arqueol., Casma, Peru. 
Gif-1081. Temple of Sechin 1

Cloth.

Gif-1082. Temple of Sechin 2

Charcoal.

Gif-1083. Temple of Sechin 3

Straw.

General Comment: temple is younger than Chavin culture.

\section{Los Naranjos series, Honduras}

Los Naranjas $\left(16^{\circ} 00^{\prime} \mathrm{N}\right.$ Lat, $88^{\circ} 33^{\prime} \mathrm{W}$ Long) is important archaeologic site of N W Honduras, $100 \mathrm{~km} \mathrm{~N} \mathrm{E} \mathrm{ceremonial} \mathrm{Mayan} \mathrm{center}$ of Capan. Comparison of ceramics of this site with Mayan area has enabled a determination of 4 cultural phases: Jaral, Eden, Yojoa, Rio Blanco. Charcoal coll. by C. F. Baudez and subm. 1967-1969 by P. Becquelin, C.N.R.S., Mus. de l'Homme, Paris.

Gif-1472. Los Naranjos, 811

$1530 \pm 100$

Hearth of habitation site, $1.70 \mathrm{~m}$ depth. Yojoa phase.

Gif-1474. Los Naranjos, 819 A.D. 420

$660 \pm 90$

Habitation soil, 2.20 to $2.40 \mathrm{~m}$ depth. Yojoa phase.

Gif-1326. Los Naranjos, 480

$1500 \pm 100$ A.D. 450

Soil of ceremonial place. Yojoa phase.

$$
\text { A.D. } 690
$$$$
1260 \pm 90
$$

Gif-1473. Los Naranjos, 812

$$
1700 \pm 100
$$

A.D. 250

Habitation soil, 2.20 to $2.30 \mathrm{~m}$ depth; 2nd part of Eden phase.

\section{Gif-1324. Los Naranjos, 152}

$1850 \pm 100$

Habitation soil, 2nd part of Eden phase.

$$
\text { A.D. } 100
$$

Gif-1475. Los Naranjos, 1304

$$
2700 \pm 110
$$

750 B.C.

Habitation soil, 4.50 to $4.70 \mathrm{~m}$ depth. Comment: probably remains of hearth of Jaral phase reworked into Eden phase level.

\section{Gif-1325. Los Naranjos, 325}

$$
3680 \pm 100
$$$$
1730 \text { B.C. }
$$

Natural burning level under 1st occupation level of site corresponding to Jaral phase.

General Comment: corresponds to estimated chronology. 
Gif-1205. Ranchillos, San Juan, Argentina, 78

A.D. 1290

$660 \pm 90$

Wood of branches from bottom of "Cassa-Pozo", $90 \mathrm{~cm}$ depth, Ranchillos (32 $05^{\prime} \mathrm{S}$ Lat, $68^{\circ} 06^{\circ} \mathrm{W}$ Long), Prov. San Juan, Argentina (Gonzalez, 1967). Coll. and subm. 1968 by A. R. Gonzalez, Fac. Sci., La Plata. Comment: assoc. with poor industry, no ceramics.

Gif-1206. Costa de Reyes, Tinogasta, Catamarca, Argentina

$1560 \pm 100$

A.D. 390

Wood from habitation level, from Excavation 1, Costa de Reyes $\left(27^{\circ} 04^{\prime} \mathrm{S}\right.$ Lat, $68^{\circ} 01^{\prime} \mathrm{W}$ Long), Tinogasta, Prov. Catamarca, Argentina. Coll. 1964 and subm. 1968 by A. R. Gonzalez. Comment: lst known culture with ceramics in Valla de Abancan, N W Argentina (Bennett et al., 1948).

\section{Gif-1265. San Vicente de Tagua-Tagua, 4, Chile 9050 в.c.}

$11,000 \pm 250$
9050 B.c.
e, San Vicente,

Charcoal, $2.35 \mathrm{~m}$ depth in lacustrine deposit on terrace, San Vicente,
Tagua-Tagua lagoon ( $34^{\circ} 30^{\prime} \mathrm{S}$ Lat, $71^{\circ} 06^{\prime} \mathrm{W}$ Long). Coll. 1967 on Tagua-Tagua lagoon $\left(34^{\circ} 30^{\prime} \mathrm{S}\right.$ Lat, $71^{\circ} 06^{\prime} \mathrm{W}$ Long). Coll. 1967
by Montané and subm. 1968 by A. Emperaire, Ecole Pratique Hautes Etudes, Sorbonne. Comment: 1st S American site with human industries assoc. with mastodon.

\section{Ponsomby series, Chile}

Site of Ponsomby lies on Fitz Roy passage in Skyring sea, Ponsomby $\left(52^{\circ} 10^{\prime} \mathrm{S}\right.$ Lat, $71^{\circ} 28^{\prime} \mathrm{W}$ Long), Riesco I. Complicated stratigraphy corresponds to series of terraces and peat bogs related to level variations of inner Skyring-Otway seas complex (Laming, 1968). Samples coll. 19521953 by J. Emperaire and subm. 1967 by A. Emperaire.

\section{Gif-1050. Ponsomby P B Y 53, A inferior}

Shell from deposit, at foot of clay cliff. Comment: industry similar to historic wandering fishermen.

\section{Gif-1049. Ponsomby P B Y 53, B}

$3720 \pm 130$ 1770 B.c.

Charcoal under Hearth $\mathbf{B}$, from archaeologic level on terrace +4 $\mathrm{m}$, in loess deposit. Comment: industry similar to that of inland pampas; may come from upper terrace which is very eroded.

Gif-1052. Ponsomby P B Y 53, D, 53 $5520 \pm 140$

Wood from tree trunks in sand.

Gif-1048. Ponsomby P B Y 3, D, 100

$6370 \pm 160$

4420 B.c.

Charcoal under lacustrine silt, lying on sand with tree trunks. Comment: assoc. fauna essentially terrestrial. Lithic industry related to those of interior inland pampas. First traces of human occupation by hunters. 
Gif-1051. Ponsomby P B Y 3, 52

$7610 \pm 170$

Vegetal debris from peat bog, just under Gif-1048. Comment: upper level of peat bog dated 6500 B.P. (Sa-47: R., 1964, v. 6, p. 243).

\section{Marassi series, S Chile}

Charcoal from rock shelter constituted by big erratic block, at Marassi (53 $30^{\prime} \mathrm{S}$ Lat, $69^{\circ} 30^{\prime} \mathrm{W}$ Long), S coast of Bahia Inutil, Strait of Magellan, Tierra del Fuego. Coll. and subm. 1965 by A. Emperaire.

Gif-1033. Marassi I, 4542

$5570 \pm 400$

Hearth D, Level 4, surface. Comment: diluted with inert carbon.

\section{Gif-1034. Marassi I, 4541}

$9590 \pm 210$

Charcoal debris dispersed in base level.

General Comment: 1st site found under rock shelter in Tierra del Fuego, dates probably most ancient appearance of man.

\section{Bahia Municioń 3 series, $\mathbf{S}$ Chile}

Charcoal from different levels of Municion 3 site, on continental coast of strait of Magellan (52 $30^{\prime} \mathrm{S}$ Lat, $70^{\circ} 30^{\prime} \mathrm{W}$ Long), in consolidated sand hill $5 \mathrm{~m}$ thick. Thirteen archaeologic levels were distinguished, separated by sterile levels. Site is very important because it is the only one in this strongly eroded region. Coll. and subm. 1967 by A. Emperaire.

Gif-1035. Bahia Municioń 3, 4242 Hearth from Level 2.

Gif-1036. Bahia Municioń 3, 4241 Level 3.

Gif-1037. Bahia Municioń 3, 4245 Level 4.

Gif-1038. Bahia Municioń 3, 4255 Level 5 .

Gif-1039. Bahia Municioń 3, 4273 Level 6.

Gif-1042. Bahia Municioń 3, 4299 Level 9.

$$
290 \pm 90
$$

$$
\text { A.D. } 1700
$$

$$
250 \pm 90
$$

A.D. 1210

$$
740 \pm 110
$$

A.D. 1150

$800 \pm 100$

$$
1680 \pm 140
$$

A.D. 270

$1990 \pm 110$

40 в.c. 
Gif-1043. Bahia Municioń 3, 4326

Base Level II.

Gif-1040. Bahia Municioń 3, 4268

$530 \pm 100$

Level 7.

A.D. 1420

Gif-1041. Bahia Municioń 3, 4269

A.D. 1400

$550 \pm 100$

Level 8.

General Comment: Levels 7 and 8 probably correspond to recent settlement at foot of sand hill. Base level dates period of forest, i.e., thermal optimum.

\section{Other Countries}

$$
1500 \pm 100
$$

Gif-1349. Venice, Italy

A.D. 450

Wood from stake, $3 \mathrm{~m}$ long, from silt of Venice Lagoon, Torcello I. (45 $26^{\prime} \mathrm{N}$ Lat, $12^{\circ} 20^{\prime} \mathrm{E}$ Long), Italy. Subm. 1969 by V. Romanovsky, Centre de Recherches et d'Etudes Océanog., Paris.

\section{Gif-1272. Magapit Bridge, Cagayan Valley, \\ $3550 \pm 110$ Philippines \\ 1600 B.C.}

Cardium in archaeologic site, presently $+40 \mathrm{~m} \mathrm{~N}$ of Cagayan Valley, N Luzon, Magapit Bridge ( $18^{\circ} 08^{\prime} \mathrm{N}$ Lat, $121^{\circ} 42^{\prime} \mathrm{E}$ Long), Philippines. Coll. and subm. 1968 by F. Delany, B.R.G.M., Paris. Site contains in situ red ceramics without decoration, polished stone tools and mollusk shells. Comment: dates Late Neolithic period in Philippines, before Chinese influence.

\section{Phom Laang series, Kampot Prov., Cambodia}

Caves with Neolithic artifacts in calcareous hill, $125 \mathrm{~km}$ E Phnom Penh-Kampot, Phnom Laang $\left(10^{\circ} 43^{\prime} \mathrm{N}\right.$ Lat, $104^{\circ} 20^{\prime} \mathrm{E}$ Long), Kampot Prov., Cambodia. Coll. and subm. 1967 by J. P. Carbonnel, Fac. Sci., Paris.

\section{Gif-873. Phnom Laang, Cave 57}

$500 \pm 90$

River shells from upper archaeologic level in Cave 57. Comment: assoc. with bony tools and human bones. Cave still presently occupied by men, a fact which may explain recent inclusion of dated shells into prehistoric level.

\section{Gif-1167. Phnom Laang, Cave 62 bis}

$4370 \pm 140$

2420 в.c.

Bone tool remains in brown silty ground of Cave 62 bis. Comment: bone collagen dated. 
Gif-1447. Chamcar Andong, Cambodia

$1150 \pm 100$

Straw debris in potsherds, in Neolithic site Chamcar Andong $\left(12^{\circ}\right.$ $22^{\prime} \mathrm{N}$ Lat, $105^{\circ} 12^{\prime}$ E Long), Kompong Cham Prov., Cambodia. Coll. and subm. 1969 by J. P. Carbonnel. Comment: shows Neolithic persistence in isolated place till Kmer period.

\section{Gif-1448. Chup, Cambodia}

$2130 \pm 100$

Straw debris in potsherds from Neolithic site, at Chup $\left(12^{\circ} 00^{\prime} \mathrm{N}\right.$ Lat, $105^{\circ} 37^{\prime}$ E Long), Kompong Cham Prov., Cambodia. Coll. and subm. 1969 by J. P. Carbonnel. Comment: same as for Gif-1447.

\section{Gif-1057. Samrong Sen, Cambodia}

$3230 \pm 120$

1280 B.C.

River shells (Corbicula and Paludina), $1.50 \mathrm{~m}$ deep in large kitchen midden (350 m long, $200 \mathrm{~m}$ wide, $5 \mathrm{~m}$ thick), on Samrong village $\left(12^{\circ}\right.$ $21^{\prime} \mathrm{N}$ Lat, $104^{\circ} 50^{\prime} \mathrm{E}$ Long), Kompong Chhnang Prov., Cambodia. Exploited till recently for lime production. Coll. and subm. 1967 by J. P. Carbonnel. Comment: abundant potsherd remains assoc.; according to Mansuy (1923) presence of bronze; hence, expected age was ca. 300 в.C. (Carbonnel and Delibrias, 1968). Beginning of occupation of this site is much older because kitchen midden base level is $3.5 \mathrm{~m}$ deeper.

\section{Gif-872. Phnom Kbal Romeas, 515, Cambodia}

$5370 \pm 140$

Kbal Kbal Romeas, $10 \mathrm{~km}$ E Kampot (10 36 08" N Lat, 104 15' E Long), Cambodia. Coll. and subm. 1967 by J. P. Carbonnel. Comment: atypical potsherds assoc.

\section{GEOLOGIC SAMPLES}

\section{A. France}

\section{1. $N$ and $W$ France}

\section{Channel Islands series}

Shelly sand from hydraulic dunes on sandy banks, submerged off the Channel Is., in Normano-Breton Gulf. Dredged and subm. 1968 by P. Hommeril, Fac. Sci., Rouen. Depths are related to lowest tide sea level (Hommeril, 1971).

Gif-1152. Shôle Bank, D 509

$4590 \pm 140$

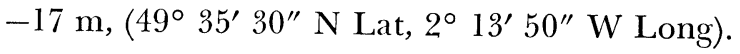

2640 B.c.

Gif-1666. Shôle Bank, D 523

$3950 \pm 100$

$-19 \mathrm{~m},\left(49^{\circ} 33^{\prime} 20^{\prime \prime} \mathrm{N}\right.$ Lat, $2^{\circ} 13^{\prime} 10^{\prime \prime} \mathrm{W}$ Long).

Gif-1663. Ecrevière Dune, D 169

2000 B.C.

$-1 \mathrm{~m},\left(49^{\circ} 17^{\prime} \mathrm{N}\right.$ Lat, $1^{\circ} 54^{\prime} \mathrm{W}$ Long). 
Gif-1664. W Serk Bank, D 296

$1830 \pm 90$

$-43 \mathrm{~m},\left(49^{\circ} 25^{\prime} 15^{\prime \prime} \mathrm{N}\right.$ Lat, $2^{\circ} 24^{\prime} 45^{\prime \prime} \mathrm{W}$ Long).

A.D. 120

Gif-1665. Great-Bank, D 299

$1300 \pm 90$

A.D. 650

$-8 \mathrm{~m},\left(49^{\circ} 26^{\prime} \mathrm{N}\right.$ Lat, $2^{\circ} 30^{\prime} 50^{\prime \prime} \mathrm{W}$ Long).

General Comment: elucidates history of submarine banks and of sedimentation in Normano-Breton Gulf.

Gif-1293. Boulogne-sur-Mer, 1, Pas-de-Calais

$3950 \pm 140$

2000 B.c.

Wood from tree trunk in littoral peat bog, $2.40 \mathrm{~m}$ above m.s.l. on beach, Boulogne-sur-Mer (50 $37^{\prime} \mathrm{N}$ Lat, $0^{\circ} 45^{\prime} \mathrm{W}$ Long), Pas-de-Calais. Coll. and subm. 1968 by H. Mariette, Samer, Pas-de-Calais. Comment: agrees well with Bronze age of site found in peat bog.

\section{Gif-1294. Camiers, 2, Pas-de-Calais}

$2100 \pm 110$

Charcoal in peaty sand, $3 \mathrm{~m}$ above m.s.l., on beach, $50 \mathrm{~m}$ from foot of cliff, Camiers (50 53' N Lat, $0^{\circ} 45^{\prime} \mathrm{W}$ Long), Pas-de-Calais. Coll. and subm. 1968 by H. Mariette. Comment: site of 2nd Iron age found at this horizon yielded abundant material for salt exploitation.

\section{Gif-1295. Camiers, 3, Pas-de-Calais}

$$
3180 \pm 140
$$

Wood in gray clay under peaty sand, $1.50 \mathrm{~m}$ above m.s.l.; on beach, $150 \mathrm{~m}$ from foot of cliff, Camiers $\left(50^{\circ} 33^{\prime} \mathrm{N}\right.$ Lat, $0^{\circ} 45^{\prime} \mathrm{W}$ Long), Pasde-Calais. Coll. and subm. 1968 by H. Mariette. Comment: agrees with Iron age industry found in this horizon. As Gif-1293 and 1294, indicates variations of sea level.

\section{Cléon series, Seine Maritime}

From base of alluvial terrace of Seine, near Cléon, alt. $+5 \mathrm{~m},\left(49^{\circ}\right.$ $18^{\prime} \mathrm{N}$ Lat, $1^{\circ} 01^{\prime} \mathrm{E}$ Long), Seine Maritime. Coll. and subm. 1968 by P. Hommeril.

Gif-1153. Cléon, Mn 1

Calcareous nodules in gray sand, 9.00 to $10.50 \mathrm{~m}$ depth.

Gif-1154. Cléon, Mn 2

Calcareous nodules in fine gray sand, 2.60 to $2.80 \mathrm{~m}$ depth.

Gif-1155. Cléon, Mn 3

Gasteropod shells from same sand as Gif-1154.

\section{Gif-1169. Colleville-sur-Mer, Calvados}

$$
8730 \pm 190
$$

Mammoth tusk from solifluction flow, cliffed on "Omaha Beach", Colleville-sur-Mer $\left(49^{\circ} 42^{\prime} \mathrm{N}\right.$ Lat, $1^{\circ} 22^{\prime} \mathrm{W}$ Long), Calvados. Coll. and subm. 1968 by C. Larsonneur, Fac. Sci., Caen. Comment: obtained on total carbon. 


\section{Coquebourg, series, Les Veys, Manche}

Borings, alt. $+3 \mathrm{~m}$, on littoral, at Coquebourg, Les Veys $\left(49^{\circ} 20^{\prime}\right.$ N Lat, $1^{\circ} 08^{\prime}$ W Long), Manche. Coll. and subm. 1968 by C. Larsonneur. Depths are related to m.s.l.

\section{Gif-1216. Coquebourg, F 9}

Peaty mud, $+1 \mathrm{~m}$.

$3050 \pm 110$

1100 B.C.

Gif-1217. Coquebourg, F 28

$13,000 \pm 300$

Fine shelly sand, $-4 \mathrm{~m}$. Comment: in absence of organic matter, total carbon, probably partly detrital, was used for measurements.

\section{Gif-1218. Coquebourg, F 35}

$7550 \pm 170$

Mud with organic matter, $-5.5 \mathrm{~m}$.

5600 B.C.

\section{Gif-1219. Coquebourg, F 52}

Muddy sand, $-11 \mathrm{~m}$. Comment: very low organic content; com. pensated with inert carbon.

General Comment: Gif-1218 corresponds to Flandrian Transgression in Les Veys Bay, whereas Gif-1219 represents ancient sediments in situ.

\section{Gif-1184. Continental shelf, Atlantic, D 16}

$1730 \pm 100$

Glycymeris shells, on edge of continental shelf, $-137 \mathrm{~m}\left(45^{\circ} 54^{\prime} \mathrm{N}\right.$ Lat, $0^{\circ} 03^{\prime} 35^{\prime \prime} \mathrm{W}$ Long), Atlantic. Coll. by dredging and subm. 1968 by M. Glémarec, Fac. Sci., Brest. Comment: it is interesting that such young shells may be dredged, so deep and so far from coast.

\section{Gif-1259. Baie d'Audierne, Finistère}

$15,000 \pm 400$

shelly sandstone of littoral facies, (n) off Baie d'Audierne $\left(47^{\circ} 58^{\prime}\right.$ ( Lat, $32^{\circ} \mathrm{W}$ Long), Finistère. Shells mixed with terrigenous gravel and pebbles; cement is of coarse sand (Saint-Requier and Guilcher, 1969). Coll. by divers and subm. 1969 by A. Guilcher, Fac. Lettres., Brest. Comment: if shore formation, as supposed, age is old for sea level at $34 \mathrm{~m}$.

\section{Gif-1214. Pont-de-Paille, Loire Atlantique}

Oyster from shelly horizon, 4.50 to $4.70 \mathrm{~m}$ depth, Pont-de-Paille $\left(47^{\circ} 18^{\prime} \mathrm{N}\right.$ Lat, $2^{\circ} 11^{\prime} \mathrm{W}$ Long), Loire Atlantique, overflow region of Grande Brière. Coll. and subm. 1968 by F. Ottmann, Fac. Sci., Nantes. Comment: corresponds to marine transgression which destroyed forest of La Grande Brière. 


\section{Gif-1271. Trizay, Charente Maritime}

Peat, from base of peaty horizon over blue-gray clay, $1.70 \mathrm{~m}$ above mean sea level, on left bank of Arnoult R., tributary of Charente R., at Trizay ( $45^{\circ} 13^{\prime} \mathrm{N}$ Lat, $3^{\circ} 15^{\prime} \mathrm{W}$ Long). Coll. and subm. 1968 by C. Gabet, Rochefort. Comment: absence of alluvium between clay and peat suggests that peat accumulation began just after Flandrian Transgression.

\section{Gif-866. Ile d'Or, Amboise, Indre et Loire}

$5000 \pm 140$

Wood (Quercus sp.), from beneath $8 \mathrm{~m}$ alluvial sand, Ile d'Or, Amboise $\left(47^{\circ} 25^{\prime} \mathrm{N}\right.$ Lat, $1^{\circ} 00^{\prime} \mathrm{E}$ Long), Indre et Loire. Coll. and subm. 1967 by J. C. Koeniger, Fac. Sci., Paris. Comment: dates beginning of alluvial plugging of Loire Valley, at Amboise.

\section{Central France}

\section{Chaine-des-Puys series, Massif Central}

Samples from beneath lava or tephra from recent episodes of volcanism of Chaîne-des-Puys, in Massif Central (Brousse et al., 1969). Unless otherwise specified, dates were obtained on organic matter in soil, humic acids being eliminated. Coll. and subm. by R. Brousse, Fac. Sci., Orsay.

Gif-1408. Pranal Flow

$\geqslant 35,000$

Wood from beneath Pranal Flow, from Chalusset Volcano, bank of Sioule R. ( $45^{\circ} 52^{\prime} \mathrm{N}$ Lat, $2^{\circ} 50^{\prime}$ E Long).

\section{Source des Roches, Chamalièr}

Organic matter from lacustrine sediments with diatoms covered with basaltic tephra probably from "Petit-Puy-de-Dôme" near Source des Roches, at Chamalières ( $45^{\circ} 47^{\prime} \mathrm{N}$ Lat, $3^{\circ} 03^{\prime}$ E Long).

\section{Gif-1409. Royat}

$$
11,000 \pm 150
$$

9050 B.c.

Paleosol on Royat Flow, covered with $5 \mathrm{~cm}$ basaltic cinder and ash, near "Grotte du Chien," at Royat ( $45^{\circ} 45^{\prime} \mathrm{N}$ Lat, 3 $03^{\prime}$ E Long).

\section{Gif-1581. Clermont-Ferrand, Boring 3}

$10,700 \pm 270$

Peaty mud from beneath $1.50 \mathrm{~m}$ black ash and $0.50 \mathrm{~m}$ diatom mud with gastropods, beneath Clermont-Ferrand $\left(45^{\circ} 47^{\prime} \mathrm{N}\right.$ Lat, $3^{\circ} 05^{\prime}$ E Long), Puy-de-Dôme. Coll. by boring and subm. by H. Pelletier.

\section{Gif-1502. Puy de Lantegy 1}

$10,000 \pm 250$

Upper paleosol, $10 \mathrm{~cm}$ thick, at top of basaltic black cinder at 1.30 
$m$ depth, on N flank Puy de Lantegy (45 $49^{\prime} \mathrm{N}$ Lat, $2^{\circ} 56^{\prime} \mathrm{E}$ Long), successively covered with $60 \mathrm{~cm}$ domitic ash rubbish, and present soil.

\section{Gif-1501. Puy de Lantegy, 2}

$8200 \pm 120$

Charcoal in domitic ash layer overlying ancient soil Gif-1502, on N flank of Puy de Lantegy.

Gif-1492. Puy de Lantegy, 3

$8900 \pm 190$ 6950 B.C.

Charcoal in acid tephra on $\mathrm{N}$ flank Puy de Lantegy, but not in the same place as Gif-1502 and 1501. Coll. by D. Baudry and subm. 1969 by $\mathrm{H}$. Tazieff.

\section{Gif-1498. Cheire de Mercoeur, V}

$8400 \pm 300$ Cheire de Merce

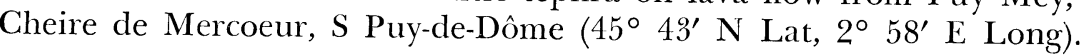

\section{Gif-1497. Cheire de Mercoeur, IV}

$8100 \pm 200$

Paleosol overlying domitic ash dated 8400 B.P.: Gif-1498, at Cheire de Mercoeur, S Puy-de-Dôme.

Gif-1499. Puy-de-Laschamp

$8200 \pm 170$ Laschamp (45 $44^{\prime} \mathrm{N}$ Lat, $2^{\circ} 57^{\prime} \mathrm{E}$ Long).

\section{Gif-1553. Saint-Saturnin I, organic remains}

$8000 \pm 170$

Organic remains of ancient soil, 30 ch Saturnin $\left(45^{\circ} 39^{\prime} \mathrm{N}\right.$ Lat, $3^{\circ} 05^{\prime} \mathrm{E}$ Long).

Gif-1552. Saint-Saturnin 1 , humic acid

$6500 \pm 300$

Organic remains from ancient soil, upper level 0 to $15 \mathrm{~cm}$, beneat lava flow of Saint-Saturnin, same place as Gif-1553.

\section{Gif-1626. Saint-Saturnin 2, humic acid}

$$
\begin{aligned}
& 5800 \pm 400 \\
& 3850 \text { B.c. }
\end{aligned}
$$

Humic acid from ancient soil, 0 to $15 \mathrm{~cm}$ beneath lava flow of Saint-Saturnin. Comment: organic remains have a similar age at top and base of paleosol but humic acids are contaminated by humic acids from upper recent soil, which percolate through fissures in basaltic flow.

\section{Gif-1500. Puy de Barme}

$7850 \pm 180$ of Puy de Barme (45 $44^{\prime}$ N Lat, $2^{\circ} 55^{\prime}$ E Long). 
Gif-1164. Puy de Montchal, 1

Fine charcoal in soil beneath $80 \mathrm{~cm}$ basaltic cinder, probably from Puy de Montchal, N lake of Pavin (45 29' N Lat, $2^{\circ} 53^{\prime} \mathrm{E}$ Long) (Brousse et al., 1969).

\section{Gif-1191. Puy de Montchal, 2}

$6650 \pm 160$

Similar to Gif-1164. Comment: confirms absence of pollution from upper charcoal horizon.

\section{Gif-1375. Puy de la Toupe}

$6000 \pm 150$

Ancient soil, $60 \mathrm{~cm}$ deep, under basaltic ash from Puy de la Vache and Puy de Lassolas and covering Puy de la Toupe $\left(45^{\circ} 41^{\prime} \mathrm{N} \mathrm{Lat,} 2^{\circ}\right.$ $56^{\prime}$ E Long).

\section{Gif-1278. N Puy du Montcineyre}

$5750 \pm 150$

Paleosol beneath $40 \mathrm{~cm}$ basaltic ash, $4 \mathrm{~km} \mathrm{~N}$ of Puy du Montcineyre (45 $27^{\prime} \mathrm{N}$ Lat, $2^{\circ} 54^{\prime} \mathrm{E}$ Long) (Brousse and Horgues, 1969).

Gif-1496. N E Puy du Montcineyre

Ancient soil overlying volcanic ash, covered with phonolitic ejecta, $2 \mathrm{~km} \mathrm{~S} \mathrm{SE} \mathrm{from} \mathrm{Puy} \mathrm{du} \mathrm{Montcineyre.}$

\section{Gif-1529. Clermont-Ferrand, Boring CRDP 7}

$$
2050 \pm 100
$$

Charcoal in black mud with gastropods, $5.50 \mathrm{~m}$ deep, beneath $3 \mathrm{~m}$ volcanic pumice Clermont-Ferrand ( $45^{\circ} 47^{\prime} \mathrm{N}$ Lat, $3^{\circ} 05^{\prime} \mathrm{E}$ Long), Puyde-Dôme. Coll. by boring and subm. by H. Pelletier, Fac. Sci., ClermontFerrand. Comment: elsewhere, upper part of pumice relates to archaeologic horizon of La Tène age. Age is consistent.

General Comment: proves existence of very recent volcanism in $\mathrm{N}$ Massif Central; one phase is contemporaneous with volcanism in Eifel dated 10,680 to 11,150 в.P. (Firbas, 1953).

\section{Lake Pavin series, Massif Central}

Lacustrine sediments from crater Lake Pavin, in Chaîne des Puys, Massif Central (45 $30^{\prime} \mathrm{N}$ Lat, $2^{\circ} 53^{\prime} \mathrm{E}$ Long). Two methods of sampling were used according to consistency of sediments:

a) sample $70 \mathrm{~cm}$ deep coll. with conventional coring equipment

b) sample $30 \mathrm{~cm}$ deep from muddy, soft, surface coll. by diver with hand-operated glass tube.

Neither pumice nor ash was found in sediments. Coll. by R. Chesselet and subm. 1968 by R. Brousse. 
Gif-1305. Pavin P 2, surface

$1250 \pm 100$

Probably surface sediment. Comment: water content of sediment was ca. $300 \%$ in glass tube.

Gif-1306. Pavin P 12, 27 to $30 \mathrm{~cm}$ depth

$4150 \pm 120$

At bottom of glass tube.

2200 в.C.

Gif-1261. Pavin, 30 to $40 \mathrm{~cm}$ depth

$6050 \pm 145$

4100 B.C.

Gif-1262. Pavin, 50 to $60 \mathrm{~cm}$ depth

$4900 \pm 130$

2950 B.c.

Gif-1263. Pavin, 70 to $80 \mathrm{~cm}$ depth

$5770 \pm 140$

3820 B.C.

Gif-1135. Pavin, 90 to $100 \mathrm{~cm}$ depth

$4150 \pm 170$

2200 B.C.

General Comment: age inversions indicate important disturbance in lake sediment, confirmed by presence of fission products from modern fallout, along $301 \mathrm{st} \mathrm{cm}$.

\section{Pont de la Clamouze series, Puy-de-Dôme}

Peat from peat bog of Pont de la Clamouze, at $1185 \mathrm{~m}$ alt. $\left(45^{\circ} 29^{\prime}\right.$ $\mathrm{N}$ Lat, $2^{\circ} 51^{\prime}$ E Long) in Puy-de-Dôme. Coll. and subm. 1968 by $\mathrm{G}$. Delibrias and R. Brousse.

$3700 \pm 130$

Gif-1162. Pont de la Clamouze, $150 \mathrm{m100} \pm 130$

1750 B.C.

2150 B.C.

General Comment: pollen analysis indicates Fagus maximum ca. 4100 B.P.

3. $S$ France

Les Estables I series, Vallespir, Bassin de la Parcigoule, Pyrénées Orientales

Peat bog Les Estables I (42 $27^{\prime} \mathrm{N}$ Lat, $2^{\circ} 27^{\prime} 07^{\prime \prime} \mathrm{E}$ Long) in Tech river basin, at $\mathrm{E}$ part of Pyrenean range, High Vallespir, alt. $1720 \mathrm{~m}$. Coll. and subm. 1968 by G. Jalut, Fac. Sci., Toulouse.

Gif-1197. Estables I, Palyn 7, 0 to 5 cm

Gif-1198. Estables II, Palyn 8, 11 to $16 \mathrm{~cm}$

Comment: evident inversion of 2 upper levels.

$$
\begin{array}{r}
1350 \pm 100 \\
\text { A.D. } 600 \\
600 \pm 90
\end{array}
$$

A.D. 1350 


\section{Gif-1199. Estables I, Palyn 9, 50 to $55 \mathrm{~cm} \quad 3170$ B.c.}

Atlantic-Sub-Boreal transition. Comment: marks extension of beech at Sub-Boreal period.

\section{Gif-1200. Estables I, Palyn 10, 72 to $79 \mathrm{~cm} \quad \mathbf{6 3 1 0} \pm 220$}

Boreal period characterized by abundant pollen of Pinus and scarcity of Abies.

General Comment: mountain vegetation of Tech river basin, as in Têt river basin (Gif-870: $8300 \pm 190$, R., 1971, v. 13, p. 236) is different from that of Aude valley where, at same period, Abies pollen is abundant (Gif-792: $9250 \pm 210$, R., 1971, v. 13, p. 236, Van Campo and Jalut, 1969). This indicates one of most important differences between types of paleosylvatic succession of Aude river basin, in $\mathrm{N}$ slope and Têt and Tech valleys which are of SW-NE orientation and where Mediterranean climate appears as determining agent of this development (Jalut, 1971).

\section{Les Estables II series, Vallespir, Bassin de la Parcigoule,}

\section{Pyrénées Orientales}

Peat bog, Les Estables II, (42 $27^{\prime} 55^{\prime \prime}$ N Lat, $2^{\circ} 26^{\prime} 45^{\prime \prime}$ E Long), Vallespir, alt. $1883 \mathrm{~m}$, Pyrénées Orientales. Coll. and subm. 1969 by G. Jalut.

Gif-1389. Les Estables II, 0 to $5 \mathrm{~cm}$

Gif-1390. Les Estables II, 45 to $55 \mathrm{~cm}$

Gif-1391. Les Estables II, 145 to $155 \mathrm{~cm}$

$$
\begin{array}{r}
\text { Modern } \\
\delta \mathbf{C}^{14}=+\mathbf{2 0 \%} \\
1100 \pm 90 \\
\text { A.D. } 850 \\
1200 \pm 90 \\
\text { A.D. } 750
\end{array}
$$

Comment: consistent with presence of cereal pollen in the 3 levels.

\section{Gif-865. La Channe R., Hautes Alpes}

$8500 \pm 200$

Tree trunk rooted in silty layer buried by mud flow of marl $9 \mathrm{~m}$ deep in terrace of La Channe R., tributary of Buëch R., affluent of Durance R., Hautes Alpes (44 $24^{\prime} \mathrm{N}$ Lat, $5^{\circ} 45^{\prime} \mathrm{E}$ Long). Coll. and subm. 1964 by M. Archambault, Fac. Lettres, Orléans, Loiret. Comment: corresponds to retreat of a glacier leading to solifluction.

\section{Gif-1080. Turrone I, Chauranne Valley, $\quad 7960 \pm 185$ Hautes Alpes \\ 6010 B.c.}

Tree trunk still rooted in Jurassic marl and buried by mud flow, $8 \mathrm{~m}$ deep, in terrace of Turrone torrent, tributary of Buëch R., St-Pierred'Argençon (44 31' 45" N Lat, $5^{\circ} 41^{\prime} 54^{\prime \prime}$ E Long), Hautes Alpes. Coll. and subm. 1967 by M. Archambault. Comment: same as for Gif-865. 
Gif-1138. Le Villard, La Beaume, Hautes Alpes

Fossilized trunks in sink hole bottom, in colluvium at top of black Jurrasic marl, on folding above Villard hamlet, La Beaume (44 $33^{\prime}$ 32" N Lat, $5^{\circ} 40^{\prime}$ 34" E Long), Hautes Alpes. Coll. and subm. 1968 by M. Archambault.

\section{Gif-1139. Melve, Hautes Alpes}

$8970 \pm 210$

Tree trunk rooted in $40 \mathrm{~cm}$ silt level, covered by stratified silty and marly debris, $6 \mathrm{~m}$ deep in bank of La Sausse Ravine, affluent of the

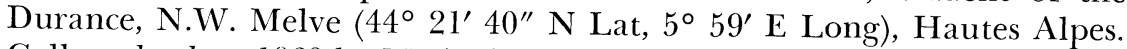
Coll. and subm. 1968 by M. Archambault. Comment: same as for Gif-865.

\section{Corsica series}

Shells from coastal sediment in Corsica (Ottmann, 1958). Coll. and subm. by F. Ottmann, Fac. Sci., Nantes.

\section{Gif-1207. Urbino, Corsica}

$23,800 \pm 700$

Cardium from Urbino pond, alt 0.50 to $1 \mathrm{~m}\left(42^{\circ} 03^{\prime} \mathrm{N}\right.$ Lat, $0^{\circ}$.

$40^{\prime \prime}$ E Long) on E coast Urbino Peninsula, Corsica.

\section{Gif-1208. Vadina, Corsica}

$24,100 \pm 700$

Cardium from Vadina, alt. ca. $+20 \mathrm{~m}\left(42^{\circ} 03^{\prime} \mathrm{N}\right.$ Lat, $9^{\circ} 26^{\prime} 30^{\prime \prime}$

E Long), Corsica Lagoon facies.

\section{Gif-1209. Figari Gulf, Corsica}

$23,100 \pm 700$

Oysters from far end of Figari Gulf, alt. $+3 \mathrm{~m}\left(41^{\circ} 27^{\prime} \mathrm{N}\right.$ Lat, $9^{\circ}$ $01^{\prime}$ E Long), Corsica. Level of lagoon facies.

Gif-1210. Arbitro Cove, Corsica $\geqslant 40,000$

Shells from Arbitro Cove, alt. 1.5 to $2 \mathrm{~m}\left(41^{\circ} 27^{\prime} \mathrm{N}\right.$ Lat, 9 $9^{\circ} 01^{\prime}$ E Long), Corsica. Assoc. with important sand dunes and organogenic calcareous sandstone. Marine facies.

\section{Gif-1211. Saint-Florent Gulf, Corsica}

Shells from Saint-Florent Gulf, alt. 1.5 to $2 \mathrm{~m}\left(42^{\circ} 42^{\prime} \mathrm{N}\right.$ Lat, $9^{\circ}$ $19^{\prime} 30^{\prime \prime} \mathrm{E}$ Long), Corsica. Assoc. with important dune formations and organogenic calcareous sandstone. Marine facies.

\section{Gif-1212. S Ajaccio Gulf, Corsica}

Shells from cove between Capo Muro and Capo Nero, $S$ Ajaccio Gulf, alt. $2.5 \mathrm{~m}\left(41^{\circ} 43^{\prime} \mathrm{N}\right.$ Lat, $8^{\circ} 42^{\prime} \mathrm{E}$ Long), Corsica. Marine facies. General Comment (F.O.): for a region of recent strong tectonic instability, alt. of coastal sites is not very significant. Yet, results do not fully disagree with faunal study. 
Shells (Melania tuberculata) from upper part of silt layer, $60 \mathrm{~cm}$ thick, in terrace $4 \mathrm{~m}$ above bottom of Nioum Wadi $\left(14^{\circ} 05^{\prime} \mathrm{N}\right.$ Lat, $14^{\circ}$ 28' E Long) Kanem, Chad. Coll. and subm. 1969 by B. Dupont, ORSTOM, Fort-Lamy, Chad. Comment: dates one of last transgressions of Chad lake, or, more probably, residual pond fed by ground water.

\section{Gif-1236. Kalia Wadi, Kanem, Chad, D.844}

Modern

Charcoal and ash from iron working kiln dug into diatomite, Kalia Wadi (14\% $18^{\prime} \mathrm{N}$ Lat, $14^{\circ} 54^{\prime} \mathrm{E}$ Long), Kanem, Chad. Coll. and subm. 1969 by B. Dupont. Comment: unrelated to age of diatomite, which is much older.

Gif-1237. Matafo Fo, Bol, Chad, D.928

Modern

Shells (Bellamya unicolor) from shelly deposit, alt. 285 to $287 \mathrm{~m}$, on dune, Matafo (13 $31^{\prime} \mathrm{N}$ Lat, $14^{\circ} 41^{\prime} \mathrm{E}$ Long), Bol, Chad. Coll and subm. 1969 by B. Dupont. Comment: correct for shoreline of Chad lake at this alt.

\section{Bimba, Mayo Mali series, Cameroun}

Superposed paleosols, in Quaternary sediments forming terraced glacis of Mayo Mali which crosses Alantika Mts., near Bimba, W Cameroun ( $8^{\circ} 34^{\prime} \mathrm{N}$ Lat, $12^{\circ} 31^{\prime} \mathrm{E}$ Long). Coll. and subm. 1968 by J. Hervieu, Centre ORSTOM, Yaoundé. In Cameroun, accumulation of this ancient alluvium is related to an erosion cycle with drier climate than at present; soils were developed during short humid cycles which stopped sedimentation (Hervieu, 1970).

Gif-1319. Mayo Mali, W J 12

$16,900 \pm 500$

$5 \mathrm{~m}$ deep in Sec. $\mathrm{c}$ of terrace. Comment: ancient $\mathrm{CO}^{2}$ added for measurement.

Gif-1320. Mayo Mali, W J 11

$19,000 \pm 600$

$8 \mathrm{~m}$ deep, Sec. c.

Gif-1321. Mayo Mali, W J 10

$18,200 \pm 500$

$10 \mathrm{~m}$ deep, Sec. $\mathrm{c}$.

16,250 в.c.

Gif-1322. Mayo Mali, W J 9

$20,000 \pm 1000$

$12 \mathrm{~m}$ deep, Sec. c.

18,050 B.C.

Gif-1323. Mayo Mali, W J 14 bis

$17,500 \pm 500$

15,550 в.c.

From another sec., near Sec. c, in a similar stratigraphic position to Gif-1319 and Gif-1320. 
General Comment: in N Cameroun, this ancient alluvium is correlated with Dourounian period, one of the known main arid periods. This dry period could be a result, between $8^{\circ}$ and $12^{\circ} \mathrm{N}$, of a semi-arid climatic influence from Sahara region. Dourounian sediments appear to have been deposited during a short time and more recently than thought.

\section{Madagascar series}

Organic layers in ancient alluvial terrace, Madagascar. Coll. and subm. 1969 by F. Bourgeat, ORSTOM, Tananarive.

Gif-1335. Ambalavao, A M T 1474

$660 \pm 90$

2.10 to $2.50 \mathrm{~m}$ beneath present alluvium Ambalavao region, $\left(21^{\circ}\right.$ $01^{\prime}$ S Lat, $46^{\circ} 07^{\prime}$ E Long), S part of Highlands.

\section{Gif-1336. Tananarive plain, A T B 1200}

A.D. 1170

$780 \pm 90$

1.50 to $2.00 \mathrm{~m}$ beneath colluvium of a red ferralitic soil, in terrace bordering on Tananarive Plain (18 $50^{\prime} \mathrm{S}$ Lat, $47^{\circ} 28^{\prime} \mathrm{E}$ Long). Corresponds to top of Terrace II.

Gif-1479. Tananarive plain, H T B 1300

$24,000 \pm 1000$

8 to $8.50 \mathrm{~m}$ in Terrace II, in Tananarive Plain $\left(18^{\circ} 50^{\prime} \mathrm{S}\right.$ Lat, $47^{\circ}$ 30 ' E Long).

Gif-1480. Tananarive plain, H T B 1400

$\geqslant 35,000$ Long).

$14 \mathrm{~m}$ in Terrace II, in Tananarive Plain $\left(18^{\circ} 50^{\prime} \mathrm{S}\right.$ Lat, $47^{\circ} 30^{\prime} \mathrm{E}$

\section{Gif-1337. Ampitano, T T B 600}

Modern

$1.50 \mathrm{~m}$ deep, in alluvial Terrace $\mathrm{I}$ of Ampitano, $\mathrm{S}$ Antsirabe, in Highlands ( $20^{\circ} 02^{\prime} \mathrm{S}$ Lat, $47^{\circ} 07^{\prime} \mathrm{E}$ Long).

Gif-1338. Manjakandriana, T T B 800

$0.80 \mathrm{~m}$ deep in Terrace II, in Manjakandriana region $\left(18^{\circ} 53^{\prime} \mathrm{S}\right.$ Lat, $47^{\circ} 47^{\prime}$ E Long).

General Comment: precise chronology of formation of 2nd and recent terraces. Considering shielding role of vegetation in equatorial climate, formation of terraces could be correlated to climate phase with strong erosion: this does not imply important climatic variations, but rather changes, in duration and in intensity of dry and wet seasons.

\section{Spitsbergen series}

$$
\text { C. Arctic Regions }
$$

Shells from uplifted terraces, W coast of Spitsbergen. Coll. by A. Moign and subm. 1968 by A. Guilcher.

Gif-1256. Gipsbukta, S P I, 11 
Gif-1442. Gipsbukta, S P I, 10

$8950 \pm 200$

7000 B.C.

Whale bone, on emerged marine terrace, $+26 \mathrm{~m}$, Gipsbukta $\left(78^{\circ}\right.$ $25^{\prime}$ N Lat, $16^{\circ} 30^{\prime}$ E Long), Spitsbergen.

Gif-1443. Gipsbukta, S P I, 14

$9200 \pm 200$ 7250 B.C.

Shells from emerged marine terrace, $+55 \mathrm{~m}$, Gipsbukta $\left(78^{\circ} 25^{\prime}\right.$ $\mathrm{N}$ Lat, $16^{\circ} 30^{\prime} \mathrm{E}$ Long), Spitsbergen.

Gif-1257. Dandmannsoyra

$8850 \pm 200$

6900 B.C.

Mytilus level, alt. $10 \mathrm{~m}, 2 \mathrm{~km}$ from littoral, in Aula Valley, Dandmannsoyra ( $78^{\circ} 15^{\prime} \mathrm{N}$ Lat, $13^{\circ} 15^{\prime} \mathrm{E}$ Long), N W of Isfjord, Spitsbergen.

Gif-1258. Erdmannsflya

$9700 \pm 230$

$\mathbf{7 7 5 0}$ B.C.

Mya level, alt. $+19 \mathrm{~m}$, on a strandflat, Erdmannsflya $\left(78^{\circ} 15^{\prime} \mathrm{N}\right.$ Lat, $14^{\circ} 20^{\prime}$ E Long), $\mathrm{N}$ of Isfjord, Spitsbergen.

General Comment: compatible with previous results for other uplifted marine terraces in Spitsbergen (R., 1966, v. 8, p. 91-92; 1969, v. 11, p. $336-337$; 1964, v. 6, p. 297 ; 1965, v. 7, p. 317).

\section{Fort Chimo series, Quebec}

Peat bog, $84 \mathrm{~m}$ thick, at Fort Chimo $\left(56^{\circ} \mathrm{N}\right.$ Lat, $67^{\circ} \mathrm{W}$ Long), Quebec. Peat samples coll. and subm. 1970 by J. Malaurie.

Gif-1831. Fort Chimo 1, 0 to $12 \mathrm{~cm}$ depth

\section{Gif-1830. Fort Chimo 3, 24 to $36 \mathrm{~cm}$ depth}

\section{Gif-1829. Fort Chimo 5, 48 to $60 \mathrm{~cm}$ depth}

\section{Gif-1828. Fort Chimo 7, 72 to 84 cm depth}

$380 \pm 90$

A.D. 1570

$1860 \pm 90$

A.D. 90

$2900 \pm 110$

950 B.C.

$4020 \pm 120$

2070 B.c.

General Comment: Betula pollen dominant till ca. $30 \mathrm{~cm}$ depth; in lower part of profile, pollen of picea abundant and Alnus present. Diagram suggests change $\mathrm{S}$ to $\mathrm{N}$ forest line in Quebec. Pollen analysis by Y. Vasari, Univ. Oulu, Finland.

\section{Greenland series}

Five profiles of organic deposits from Thule area, N W Greenland coll. and subm. 1968-1970 by J. Malaurie, Centre Etudes Arct. et FinnoScandinaves, Paris. Pollen analysis by Y. Vasari.

Ita profile, Fjord Foulke

Peat bog, $52 \mathrm{~cm}$ thick, at Ita $\left(78^{\circ} 16^{\prime} \mathrm{N}\right.$ Lat, $72^{\circ} 34^{\prime} \mathrm{W}$ Long), Fjord Foulke region. 
Gif-574. Ita 3, 6 to 9 cm depth

Gif-1748. Ita 4, 9 to $12 \mathrm{~cm}$ depth

Gif-575. Ita 5, 12 to $15 \mathrm{~cm}$ depth

Gif-576. Ita $9+10,24$ to $30 \mathrm{~cm}$ depth

Gif-577. Ita 15, 42 to 45 cm depth

Gif-578. Ita 17, 48 to $52 \mathrm{~cm}$ depth
$175 \pm 90$

A.D. 1775

$330 \pm 90$

A.D. 1620

$1200 \pm 140$

A.D. 750

$1325 \pm 140$

A.D. 625

$1480 \pm 140$ A.D. 470

$1860 \pm 150$ A.D. 90

General Comment: main components of pollen diagram are Salix arcticaglauca type, Cassiope type, gramineae and Cerastium-stellacia type. Between 500 and 750 A.D. pollen density and rate of formation of peat are maximum.

\section{Idglolorssuit profile, Robertson Fjord}

Peat bog, $82 \mathrm{~cm}$ thick, at Idglolorssuit $\left(77^{\circ} 50^{\prime} \mathrm{N} \mathrm{Lat,} 70^{\circ} 18^{\prime} \mathrm{W}\right.$ Long), Robertson Fjord region.

Gif-568. Idglolorssuit, 2, 3 to $6 \mathrm{~cm}$ depth A.D. 1860

$$
90 \pm 90
$$

Gif-569. Idglolorssuit, 4, 9 to $12 \mathrm{~cm}$ depth

$$
580 \pm 100
$$

Gif-1746. Idglolorssuit, 7, 18 to $21 \mathrm{~cm}$ depth

A.D. 1370

A.D. 1200

Gif-1747. Idglolorssuit, 9, 23 to $26 \mathrm{~cm}$ depth

A.D. 1250

$$
700 \pm 100
$$

A.D. 1170

$780 \pm 100$

A.D. 1370

$$
580 \pm 100
$$

Comment: aberrant date for unknown reason.

Gif-572. Idglolorssuit, 15, 42 to $45 \mathrm{~cm}$ depth

A.D. 1220

$$
730 \pm 100
$$

Gif-573. Idglolorssuit, 27, 78 to $82 \mathrm{~cm}$ depth

$$
1250 \pm 100
$$
A.D. 700

General Comment: gramineae pollen predominant throughout profile. Maximum pollen density and rate of peat formation from A.D. 1200 to 1400. 
Thulé profile

Peat bog, $66 \mathrm{~cm}$ thick, at Thulé $\left(76^{\circ} 35^{\prime} \mathrm{N}\right.$ Lat, $68^{\circ} 57^{\prime} \mathrm{W}$ Long).

Gif-1650. Thulé 3,5 to $8 \mathrm{~cm}$ depth

A.D. 1640

$\mathbf{3 1 0} \pm 90$

Gif-1651. Thulé 8, 19 to 21 cm depth

A.D. 1550

$400 \pm 90$

Gif-1691. Thulé 10, 24 to $27 \mathrm{~cm}$ depth

$640 \pm 90$

A.D. 1310

$750 \pm 90$

Gif-1652. Thulé 12, 30 to $32 \mathrm{~cm}$ depth

A.D. 1200

$900 \pm 90$

Gif-1692. Thulé 13, 32 to $35 \mathrm{~cm}$ depth

A.D. 1050

Gif-1693. Thulé 15, 39 to $41 \mathrm{~cm}$ depth

$$
\begin{aligned}
& 1120 \pm 90 \\
& \text { A.D. } 830
\end{aligned}
$$

$1170 \pm 100$

Gif-1754. Thulé 18, 47 to $50 \mathrm{~cm}$ depth A.D. 780

Gif-1755. Thulé 22, 57 to $60 \mathrm{~cm}$ depth

$$
1330 \pm 100
$$$$
\text { A.D. } 620
$$

$1350 \pm 100$

Gif-1549. Thulé 24, 63 to $66 \mathrm{~cm}$ depth

$$
\text { A.D. } 600
$$

General Comment: upper part of profile dominated by gramineae pollen till ca. A.D. 1300. Cyperaceae dominates in lower part. Rapid rate of peat formation ca. A.D. 800 and from A.D. 1550 to 1650 .

Ivsugissok profile

Peat bog, $55 \mathrm{~cm}$ depth, at Ivsugissok $\left(76^{\circ} 30^{\prime} \mathrm{N}\right.$ Lat, $68^{\circ} \mathrm{W}$ Long).

Gif-1648. Ivsugissok 1, 5 to $10 \mathrm{~cm}$ depth A.D. 1900

$50 \pm 50$

Gif-1649. Ivsugissok 4, 20 to $25 \mathrm{~cm}$ depth

A.D. 1800

$$
150 \pm 50
$$

$550 \pm 90$

Gif-1749. Ivsugissok 6,30 to $35 \mathrm{~cm}$ depth A.D. 1400

Gif-1750. Ivsugissok 8, 40 to $45 \mathrm{~cm}$

$$
950 \pm 90
$$

A.D. 1000

$1060 \pm 90$

Gif-1550. Ivsugissok 10,50 to $55 \mathrm{~cm}$

A.D. 890

General Comment: pollen diagram shows constant dominance of gramineae. 
Savigssivik profile

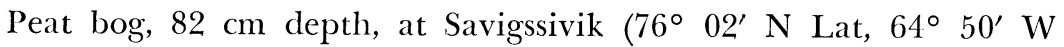
Long).

Gif-1806. Savigssivik 1, 0 to $7 \mathrm{~cm}$ depth

$1320 \pm 90$

A.D. 630

Gif-1646. Savigssivik 2,8 to $15 \mathrm{~cm}$ depth

$1400 \pm 90$

A.D. 550

Gif-1751. Savigssivik 3, 15 to $22 \mathrm{~cm}$ depth

$1370 \pm 90$

A.D. 580

Gif-1647. Savigssivik 5, 29 to $36 \mathrm{~cm}$ depth

$1450 \pm 90$

A.D. 500

Gif-1752. Savigssivik 6,36 to $43 \mathrm{~cm}$ depth

$1460 \pm 90$

A.D. 490

Gif-1753. Savigssivik 9, 60 to $68 \mathrm{~cm}$ depth

$1480 \pm 90$ A.D. 470

$1300 \pm 100$

Gif-1551. Savigssivik 11, 75 to $82 \mathrm{~cm}$ depth A.D. 650

General Comment: peat bog formation stopped ca. A.D. 600 . Rapid formation due to proximity of peat bog nidifying birds.

\section{Other Countries}

Gif-1192. Signal de Bougy, Vaud, Switzerland

Sapropelic lignite in clayey moraine, under Signal de Bougy $\left(46^{\circ}\right.$ $29^{\prime}$ N Lat, $6^{\circ} 22^{\prime}$ E Long), Vaud. Switzerland. Coll. by A. Jeannet and subm. 1968 by J. P. Vernet, Geneva.

Gif-1193. Mine de Grandson, Vaud, Switzerland

Sapropelic lignite in mine de Grandson $\left(46^{\circ} 29^{\prime} \mathrm{N}\right.$ Lat, $6^{\circ} 38^{\prime} \mathrm{E}$ Long), Vaud, Switzerland. Coll. and subm. 1968 by J. P. Vernet.

\section{Eastern Coastal Area series, Belgium}

Shells and peat coll. by coring to study lithostratigraphy of Quaternary sediments in E coastal area, Belgium. Subm. by C. Sys, Geol. Inst., Gent.

Gif-1339. Meetkerke, 124 MB, m 8

Shells in sand, $2.50 \mathrm{~m}$ depth, Meetkerke $\left(51^{\circ} 13^{\prime} 07^{\prime \prime} \mathrm{N}\right.$ Lat, $3^{\circ} 08^{\prime}$ 48" E Long).

Gif-1341. Meetkerke, 124 MB 14, m 17

Shells (Hydrobia) in clayey Meetkerke formation 5.50 to $7.00 \mathrm{~m}$ depth, (51 $11^{\circ} 07^{\prime \prime} \mathrm{N}$ Lat, $3^{\circ} 08^{\prime} 48^{\prime \prime} \mathrm{E}$ Long). 
Gif-1342. Stalhille, 124 DB 1, m 31

Shells in shelly sand, $8 \mathrm{~m}$ depth, Stalhille $\left(51^{\circ} 13^{\prime} 08^{\prime \prime} \mathrm{N}\right.$ Lat, $3^{\circ}$ $04^{\prime} 29^{\prime \prime}$ E Long).

Gif-1344. Zuienkerke, 124 DB 6, m 60

Shells in coarse sand, $23.5 \mathrm{~m}$ depth, Quienkerke $\left(\begin{array}{llll}51^{\circ} & 16^{\prime} & 03^{\prime \prime} \mathrm{N}\end{array}\right.$ Lat, 3० $09^{\prime} 39^{\prime \prime}$ E Long).

Gif-1343. Wenduine, 48 DB 3, m 37

Shell debris in shelly sand, $14 \mathrm{~m}$ depth, Wenduine $\left(51^{\circ} 18^{\prime} 30^{\prime \prime}\right.$ $\mathrm{N}$ Lat, $3^{\circ} 05^{\prime} 52^{\prime \prime}$ E Long).

Gif-1340. Litherke, 48 DB 2, m 16

$5300 \pm 130$

Peat, $3.50 \mathrm{~m}$ depth, Litherke ( $51^{\circ} 17^{\prime} 35^{\prime \prime} \mathrm{N}$ Lat, $3^{\circ} 07^{\prime} 14^{\prime \prime}$ E Long). General Comment: conclusions only for Gif-1340: Atlantic, Gif-1344: probably Eemien; Gif-1343: fits very well between both in good agreement with stratigraphy (de Breuck et al., 1969).

Gif-1239. Gli Astroni, Phlegrean Fields, Campania, Italy

Carbonized branch, $10 \mathrm{~m}$ under fine-grained tephra, E flank of Gli Astroni, one of most important volcanoes of Phlegrean Fields, N Solfatara $\left(40^{\circ} 45^{\prime} \mathrm{N}\right.$ Lat, $14^{\circ} 27^{\prime} \mathrm{E}$ Long), Campania, (Delibrias et al., 1969). Coll. and subm. 1968 by G. Kieffer, Inst. Geog., Clermont-Ferrand. Comment: confirms Late Neolithic age assigned to Astroni owing to industry found beneath tephra.

Gif-1605. Valle del Bove, Etna 69-I

$5000 \pm 130$ 3050 B.C.

Carbonized tree trunk from forest buried under 2 to $3 \mathrm{~m}$ ash, outer flank of Valle del Bove, $2 \mathrm{~km} \mathrm{~S} \mathrm{E} \mathrm{Mt.} \mathrm{Zoccolaro,} 1650 \mathrm{~m}$ alt. $\left(37^{\circ} 42^{\prime}\right.$ $30^{\prime \prime} \mathrm{N}$ Lat, $15^{\circ} 06^{\prime} 30^{\prime \prime} \mathrm{E}$ Long), S E Etna. Coll. and subm. 1970 by G. Kieffer. Comment: dates last episode of formation of caldera, $4 \mathrm{~km}$ wide on E flank of Etna (Kieffer, 1970).

Gif-1766. Etna, 70-3

$7100 \pm 140$ 5150 B.c.

Carbonized tree trunk from 2 to $4 \mathrm{~m}$ below surface of pumice and covered in places with deposit dated 5000 B.P. (Gif-1605), $2 \mathrm{~km} \mathrm{~S} \mathrm{E} \mathrm{Mt.}$ Zoccolaro, S E Etna $\left(37^{\circ} 45^{\prime} \mathrm{N}\right.$ Lat, $15^{\circ} 00^{\prime} \mathrm{E}$ Long). Coll. and subm. 1970 by G. Kieffer.

\section{Gif-1942. Vesuvius 71-I}

$1850 \pm 100$

Carbonized wood, $2 \mathrm{~m}$ below top of pumice on $\mathrm{W}$ flank of Vesuvius, $560 \mathrm{~m}$ alt. $\left(40^{\circ} 49^{\prime} 30^{\prime \prime} \mathrm{N}\right.$ Lat, $14^{\circ} 26^{\prime} 30^{\prime \prime} \mathrm{E}$ Long), Italy. Coll. and subm. 1971 by G. Kieffer. Comment: had been supposed to date eruption of Vesuvius before catastrophe of A.D. 79; in fact, dates this very event. 


\section{Asturias series, Spain}

Shells from Asturias coast, Spain, 0.50 to $1 \mathrm{~m}$ above high sea level. Coll. and subm. 1968 by G. Mary, Fac. Sci., Le Mans.

\section{Gif-1267. La Fontias, Asturias}

$1920 \pm 110$

Patella carulea and vulgata, $2 \mathrm{~m}$ above high sea level, Las Fontias (43 $33^{\prime} 30^{\prime \prime} \mathrm{N}$ Lat, $3^{\circ} 19^{\prime} \mathrm{W}$ Long), Asturias.

\section{Gif-1268. Salias, Asturias}

Cardium edula from shelly deposit at high sea level, Salias $\left(43^{\circ} 31^{\prime}\right.$ $30^{\prime \prime} \mathrm{N}$ Lat, $3^{\circ} 19^{\prime} 40^{\prime \prime} \mathrm{W}$ Long), in Ria de Ribadeo, Bahia, Asturias.

\section{Gif-1269. Salias de Granda, Asturias}

Modern

Gryphea angulata, from shelly deposit, at high tide sea level limit, covered with silt, Salias de Granda (43 $30^{\prime} 40^{\prime \prime}$ N Lat, $3^{\circ} 21^{\prime} \mathrm{W}$ Long), El Vintero, in Ria de Ribadeo, Asturias.

Gif-1270. Las Aceas, Asturias

Patella, from high tide sea level, Las Aceas, $\left(43^{\circ} 31^{\prime} 20^{\prime \prime} \mathrm{N}\right.$ Lat, $3^{\circ} 22^{\prime}$ W Long), Ria de Ribadeo, Asturias.

General Comment: Gif-1268-1270 are shells presently deposited by sea in Ria de Ribadeo.

\section{Gif-1123. Tekich, Barrada Valley, Syria}

Organic layers intercalated in upper layers of lacustrine sediment at Ickiah (33 $33^{\prime} \mathrm{N}$ Lat, $36^{\circ} 18^{\prime} \mathrm{E}$ Long), $25 \mathrm{~km} \mathrm{~N}$ W Damas, Barrada Valley, Syria. Coll. and subm. 1967 by K. Kaiser, Freien Univ., Berlin. Comment: disagrees with expected age: ca. 20,000 B.P. Corresponds to a Neolithic Pluvial.

\section{El Laklouk series, Lebanon}

Samples from base of solifluction layer, NNE El Laklouk, ca. 43 $\mathrm{km} \mathrm{N}$ E Beirut (35 $52^{\prime} \mathrm{N}$ Lat, $34^{\circ} 06^{\prime} \mathrm{E}$ Long), Lebanon. Coll. and subm. 1967 by K. Kaiser.

Gif-1124. El Laklouk, 3

Wood, $3 \mathrm{~m}$ depth.

Gif-1125. EI Laklouk, 4

Charcoal, 2 to $3 \mathrm{~m}$ depth.

General Comment: corresponds to moist period, as for Gif-1123.

\section{Cabo Frio series, Brazil}

Calcareous nodule, $5 \mathrm{~cm}$ diam., off Cabo Frio, $89 \mathrm{~m}$ depth, Rio de Janeiro (22 $53^{\prime} \mathrm{S}$ Lat, $41^{\circ} 04^{\prime} \mathrm{W}$ Long), Brazil. Formed with concentric layers of Bryozoa and calcareous algae. Dredged and subm. by L. M. Braga, Inst. Pesquisas da Marinha, Rio de Janeiro.
$2880 \pm 110$

930 B.C.

$4590 \pm 140$

2640 B.c. 
Gif-1327. Cabo Frio, internal part

$1050 \pm 100$

Gif-1471. Cabo Frio, superficial part

A.D. 900

Modern General Comment: recent formation. Cabro Frio is in warm current of Brazil.

\section{Aoba Island series, New Hebrides}

Buried formation covered by present soil and including 4 volcanic series, each with fossil soil above coarse and fine emissions, Aoba I. (15 $20^{\prime}$ S Lat, $167^{\circ} 55^{\prime}$ E Long), New Hebrides. Coll. 1966 and subm. 1967 by P. Quantin.

Gif-1134. Aoba Island, 2468

$$
1130 \pm 110
$$
point.

Charcoal from hearth, $1 \mathrm{~m}$ deep, with ceramic debris and arrow

\section{Gif-1133. Aoba Island, 2463}

$$
1550 \pm 110
$$

Brown soil, 3.00 to $3.20 \mathrm{~m}$ deep.

General Comment: indicates 4 periods of volcanic activity in $400 \mathrm{yr}$. Time required for soil formation after volcanic eruption is very short in moist tropical climate.

\section{Tongoa Island series, New Hebrides}

Organic samples from system of basaltic flows and ejecta in volcanic formations, Tongoa I. (16 $54^{\prime} \mathrm{S}$ Lat, $168^{\circ} 33^{\prime} \mathrm{E}$ Long), New Hebrides. Coll. 1965 and subm. 1967 by P. Quantin, ORSTOM, Noumea, New Caledonia.

Gif-1131. Meriu, Tongoa I., 1550

Carbonized tree trunk, $10 \mathrm{~m}$ under present soil in pumice and obsidian tephra.

\section{Gif-1132. Burika, Tongoa I., 1603}

$$
1670 \pm 110
$$

Brown soil, 3.00 to $3.20 \mathrm{~m}$ deep. pumice and ash, overlying ancient flow.

General Comment: dates 2 of last emissions of pumice from the volcano.

\section{Gif-1493. Cave of Chua Hang, Hon Chông, $\quad 4150 \pm 140$ S Viet Nam \\ 2200 B.C.}

Oyster shells in marine terrace, $+2 \mathrm{~m}$, Cave of Chua-Hang $\left(10^{\circ} 08^{\prime}\right.$ $\mathrm{N}$ Lat, $104^{\circ} 38^{\prime}$ E Long), S Viet Nam (Fontaine, 1970). Coll. and subm. by J. P. Carbonnel. Comment: dates recent sea level as in many places in Pacific. 
Gif-1713. Cai-Lây, Mekong Delta, Viet Nam

$4500 \pm 110$

2550 B.C.

Marine and tidal-marsh shells from ancient shore, $100 \mathrm{~km}$ from present littoral, at Cai-Lây $\left(10^{\circ} 24^{\prime} 15^{\prime \prime} \mathrm{N}\right.$ Lat, $106^{\circ} 07^{\prime} 30^{\prime \prime}$ E Long), in Mekong Delta. Coll. and subm. by H. Fontaine, Service Geol., Saigon. Comment: dates recent sea transgression, as Gif-1493 (Fontaine, 1971).

\section{Gif-1413. Dong Nai, Viet Nam}

$\geqslant 35,000$

Carbonized wood in clay lentil, $5 \mathrm{~m}$ below surface of sandy alluvial terrace, Dong Nai Valley (10 $0^{\circ} 55^{\prime} \mathrm{N}$ Lat, $106^{\circ} 51^{\prime} 30^{\prime \prime} \mathrm{E}$ Long), S Viet Nam. Coll. by H. Fontaine and subm. by J. P. Carbonnel. Comment: confirms alluvium is not recent.

\section{Correction}

Gif-721, v. 13, p. 228 should read: Gif-727.

Gif-1060, v. 13, p. 236 should read: Gif-1069.

\section{REFFRENCES}

Bennett, W. C., Bleiler, E. P., and Sommer, F. H., 1948, Northwest Argentine archeology: Yale Univ. Pubs. Anthropol., no. 38.

Bocquet, A. and Papet, J., 1966, La Grotte des Sarrazins: Soc. Dauphinoise d'Ethnol. Archeol. Bull., v. 66, p. 119-124.

Bouisset, P. and Guilaine, J., 1966, Datation radiocarbone d'un gisement chalcolithique du Narbonnais: Soc. Prehist. France Bull., v. 66, no. 3, p. 83-85.

Breuck de, W., Moor de, G., and Marechal, R., 1969, Litostratigrafie van de kwartaire sedimenten, in het Oostelijk Kutsgebied, Belgie: Natuurw. schappelijk Tijdschr., v. 51, p. $125-137$.

Brousse, R., Delibrias, G., Labeyrie, J., and Rudel, A., 1969, Elements de chronologie des éruptions de la Chaîne des Puys: Soc. Geol. France Bull., ser. 7, v. 11, p. 770793.

Brousse, R. and Horgues, M., 1969, Le volcan de Montcineyre, l'un des plus récents d'Auvergne: Acad. Sci. [Paris] Comptes rendus, v. 269, p. 1815-1818.

Camps, G., Delibrias, G., and Thommeret, J., 1968, Chronologie absolue et succession des civilisasions préhistoriques dans le Nord de l'Afrique: Libyca, v. 16, p. 9-28.

Carbonnel, J. P. and Delibrias, G., 1968, Premières datations absolues de trois gisements néolithiques cambodgiens: Acad. sci. [Paris] Comptes rendus, v. 267, p. 1432-1434.

Castel, G. and Giot, P. R., 1968, Le souterrain de l'Age de Fer de Kersulvez en Pluzunet, Côtes du Nord; Annales Bretagne, v. 76, no. 1, p. 97-107.

Coursaget, J. and Le Run, J., 1966, Gif-sur-Yvette natural radiocarbon measurements I: Radiocarbon, v. 8, p. 128-141.

Courtin, J., 1968, Recherches sur le Néolithique Provençal: Cahiers Ligures Préhist. Archéol., no. 17, p. 220-229. p 282-300.

Delibrias, G., Guillier, M. T., and Labeyrie, J., 1964, Saclay natural radiocarbon measurements I: Radiocarbon, v. 6, p. 233-250. $421-443$ 213-254. 1971, Gif natural radiocarbon measurements VI: Radiocarbon, v. 13, p.

Delibrias, G., Kieffer, G., and Pelletier, H., 1969, Datation par la méthode du Carbone 14 de l'Astroni, volcan des Champs Phlégréens, Campanie: Acad. sci. [Paris] Comptes rendus, v. 269, p. 2070-2071.

Evin, J., Longin, R., Marien, G., and Pachiaudi, Ch., 1971, Lyon natural radiocarbon measurements II: Radiocarbon, v. 13, p. 52-73.

Filipowiak, W., 1968, Contribution aux recherches sur la capitale du royaume du Mali à l'époque du Haut Moyen age, Afrique Occidentale: Archaeol. Polona, v.
10, p. 217-232. 
Firbas, F., 1953, Das absolute alter der Jüngsten vulkanischen eruptionen in Bereich das Laacher Sees: Naturwissenschaften, v. 40, p. 54-55.

Fontaine, H., 1970, Note sur les régions de Ha-Tiên et de Hon-Chông: Archives Géol. Viet Nam, Saïgon v. 2, no. 13, p. 126.

1971, Trace d'un ancien rivage marin à Cai-Lâg, Sud Viet Nam: Archives Géol. Viet Nam, v. 13, no. 2, in press.

Giot, P. R., 1969, Chronique des datations radiocarbone armoricaine: Annales Bretagne, v. 76, no. 1, p. 153-162.

1970, Chronique des datations radiocarbone armoricaines: Annales Bretagne, v. 77 , no. 1, p. $155-160$.

Gonzalez, A. R., 1967, Una excepcional Pieza de Mosaico del N.O. Argentina: Etnia, Mus. Etno. Municipal "Damaso Arce", Olavarria Pcia de Buenos-Aires, Argentine.

Gouletquer, P. L., 1969, Le souterrain de l'Age de Fer de Bel-Air en 'Tréby, Côtes du Nord: Annales Bretagne, v. 76, no. 1, p. 37-47. 1969, Le souterrain de l'Age de Fer de Frèche en Plény, Côtes du Nord: Annales Bretagne, v. 76, no. 1, p. 49-59.

Guilaine, J. and Abelanet, J., 1965, La céramique poladienne du Roussillon et du Bassin de l'Aude: Actes, symposium préhist. peninsular, Pamplona, p. 138.

Hervieu J., 1970, Influence des changements de climat quaternaires sur le relief et les sols du Nord-Cameroun: Annales Geog., no. 433, p. 386-398.

Hommeril, P., 1971, Datation absolue de sédiments bioclastiques provenant des bancs sous-marins du Golfe Normano-Breton, Acad. sci. [Paris] Comptes rendus, in press.

Jalut, G., 1971, Analyse pollinique de sédiments des Pyrénées Orientales: Tourbière de la Borde: haute vallée de la Têt, alt. $1660 \mathrm{~m}$, gisement des Estables I: Haut Vallespir, alt. $1750 \mathrm{~m}$ : Assoc. Fr. étude Quaternaire, Bull. no. 27, v. 2, p. 91-110.

Kieffer, G., 1970, Une ultime phase d'activité explosive de la Valle del Bove (Etna) vieille de $5000 \pm 130$ ans et ses enseignements sur l'histoire récente du grand volcan sicilien: Acad. sci. [Paris] Comptes rendus, v. 270, p. 3198-3201.

Laming-Emperaire, A., 1968, Missions archéologiques françaises au Chili austral et au Brésil méridional: Soc. Américanistes Jour., v. 57, p. 76-99.

Lebeuf, J. P., 1969, Essai de chronologie Sao; Inst. Natl. Tchadien Sci. Humaines Mém., Fort Lamy, p. 234-241.

Mansuy, H., 1923, Résultats de nouvelles recherches effectuées dans le gisement préhistorique de Samrong Sen: Service. Géol. (Indochine) Mém., no. 10, fasc. 1, p. 24.

Marmier, F. and Trécolle, G., 1968, Stratigraphie du gisement d'Hassi-Mouillah, Région de Ouargla, (Algérie): C.R.S.M. extr., no. 4, p. 121-127.

Ottmann, F., 1958, Les formations pliocìnes et quaternaires de la Corse, Soc. Géol. Fr. Mem., v. 37 , no. 84 , fasc. 15 .

Rodriguez, G., 1968, Le Néolithique dans le Saintponais (Hérault): Soc. Préhist. Fr. Bull., v. 65 , no. 3, p. 699-748.

Saint-Requier, A. and Guilcher, A., 1969, Un grès coquillier de faciès littoral, immergé à $-34 \mathrm{~m}$ en Baie d'Audierne (Finistère), est daté de 15,000 ans avant l'actuel: Acad. sci. [Paris] Comptes rendus, v. 268, p. 1915-1916.

Sanquer, R. and Galliou, P., 1970, Le château gallo-romain de Keradennec en SaintFrégant (Finistère): Annales Bretagne, v. 77, no. 1, p. 163-225.

Simmonet, R., 1970, Habitat et fonderie protohistoriques à Carbon, Commune de Varilhes (Ariège): Gallia Préhist., v. 13, fasc. 1, p. 151-216.

Thommeret, J. and Rapaire, J. L., 1964, Monaco radiocarbon measurements I: Radiocarbon, v. 6, p. 194-196.

Thommeret, J. and Thommeret, Y., 1969, Monaco radiocarbon measurements III: Radiocarbon, v. 11, p. 118-129.

Van Campo, M. and Jalut, G., 1969, Analyse pollinique de sédiments des Pyrénées Orientales: Lac de Balcère (1765m): Pollen et spores, v. 11, no. 1, p. 117-126. 